\title{
CIRCULATORY CHANGES IN SEVERE PULMONARY EMPHYSEMA BY
}

\author{
J. P. D. MOUNSEY, L. W. RITZMANN, ${ }^{*}$ N. J. SELVERSTONE $†$ \\ W. A. BRISCOE, AND G. A. MCLEMORE \\ From the Department of Medicine, Postgraduate Medical School of London
}

Received July 30, 1951

Normal or even increased cardiac output was shown by McMichael and Sharpey-Schafer (1944) and by Richards (1945) to be present in failure of the circulation secondary to lung disease, and has since been considered as one of the essential features that distinguishes this condition from heart disease primarily affecting the left ventricle. The techniques of cardiac catheterization then in use, however, did not permit detailed analysis of other alterations in circulatory dynamics that might exist. With the introduction of new methods for recording the intra-cardiac pressures it has been possible to extend these studies of the circulatory changes resulting from chronic disease of the lungs and to draw some tentative conclusions as to their mechanism.

\section{MATERIALS AND METHODS}

Selection of Patients. Of a large number of patients with chronic bronchitis and emphysema available, only those suspected of having heart involvement secondary to their pulmonary disease were chosen for investigation. As a consequence, it was recognized that the pulmonary disability of this group would probably be of particularly advanced degree. Co-existing systemic hypertension ' or ischæmic heart disease did not bar inclusion in this series, but patients considered to have left ventricular failure from either of these two causes were omitted. Cases of active tuberculosis, marked kyphoscoliosis, or pneumoconiosis were also excluded. On the basis of this selection, the data obtained in 24 patients admitted to Hammersmith Hospital during the past two years were suitable for analysis.

Since these patients were studied at various stages in the course of their disease and at varying times after their admission to hospital, it was necessary to divide them into roughly comparable groups. On clinical grounds alone, the presence or absence of congestive cardiac failure was thought to be the most significant feature. When patients were judged clinically to have made some degree of recovery from congestive failure at the time of investigation, they were placed in a separate group. Thus, three groups of patients were established-Group I, those with no evidence of past or present congestive failure; Group II, those with failure at the time of study; and Group III, those recovering from a recent episode of failure.

Respiratory Studies. Respiratory function studies were carried out with the general purpose of confirming the clinical impression of pulmonary emphysema. Consequently, in most cases, only one examination was made, and this was usually at a time when recovery from any acute process had occurred, not necessarily in close time relationship to cardiac catheterization.

Lung volume subdivisions were estimated according to the method of McMichael (1939). The maximal breathing capacity was measured using the same apparatus. The degree of impairment of pulmonary mixing and the volume of poorly-ventilated lung were estimated by the helium method (Bates and Christie, 1950; Briscoe et al., 1951).

Circulatory Studies. Cardiac catheterization, with measurement of the cardiac output by the direct Fick principle and recording of the right ventricular or pulmonary artery pressures by strain gauge manometry, was carried out as previously described by Bayliss et al. (1950). Seven of the patients were catheter-

* Research Fellow of the American Heart Association.

$\dagger$ Moseley Travelling Fellow in Medicine, Harvard University.

M 
ized on two occasions: of these, five had both studies performed during a single admission for congestive cardiac failure (Cases 20-24); the remaining two were initially catheterized during recovery from an acute attack of bronchitis with associated cardiac failure, and were re-investigated during a subsequent hospital entry (Cases 15 and 16).

All catheterizations were performed in the early afternoon at least two hours after the patients had eaten a light lunch. No premedication was given. A level $5 \mathrm{~cm}$. behind the frontal plane passing through the sternal angle was chosen as the zero position to which all intracardiac pressures were referred. In several instances, however, where the antero-posterior diameter of the chest was much increased, the level was arbitrarily lowered to $7 \mathrm{~cm}$. Because orthopncea was so frequently present, most subjects had to be studied in the semi-recumbent position. In these patients, the zero level was marked on the thorax at the intersection of the zero plane with the fifth intercostal space. In most cases strain gauge recordings of the femoral or brachial arterial pressures were obtained simultaneously with the intracardiac pressures. All pressure values were averages of measurements over at least two respiratory cycles.

Oxygen consumptions were measured by Benedict-Roth spirometer or in more recent studies by Douglas bag measurements and Haldane gas analysis. In the determination of body surface area, the patient's weight on the day of catheterization was used; no attempt was made to correct for œdema. The oxygen uptake of venous and arterial blood samples was measured directly in the modified Haldane blood-gas apparatus (Latham, 1950). In calculating the percentage oxygen saturation in arterial blood, the value used for total oxygen capacity was derived from the hæmoglobin concentration measured in a photoelectric colorimeter.

Where the effects of cardiac glycosides were studied, a single dose of digoxin, varying from 0.5 to $1.5 \mathrm{mg}$., and in one instance, ouabain, $0.75 \mathrm{mg}$., was injected slowly through the catheter. Determinations of cardiac output and pressure recordings were obtained at approximately 10-minute intervals over a period of 30 to 60 minutes. Either a BLB oro-nasal mask or the Benedict-Roth spirometer was used to administer oxygen. A minimum period of six minutes was allowed for equilibration before any measurements were made.

The effects of exercise were determined in five cases. The patient carried out bicycling movements with his legs against manual resistance for two to three minutes. Right ventricular pressures were obtained immediately afterwards in all, but cardiac outputs were determined in only two subjects.

\section{Results: I. Clinical Evaluation}

The clinical data are summarized in Table I. There were 20 men and 4 women in the series with an average age of 53 years; their occupations varied widely. Pulmonary symptoms ranged, in total duration, from 6 to 40 years; and three major patterns of onset of these symptoms were noted. Many patients had been subject to repeated episodes of winter colds and " bronchitis," which gradually increased in severity and began to recur each year. Several others dated their symptoms from a specific respiratory illness, which was usually described as " pneumonia." Thirdly, a few patients with long histories of asthma had noted the gradual development of a persistent cough. Regardless of the type of onset, the symptoms had become similar in all patients. Each had a round-the-year cough, usually productive of sputum, and gradually all had developed dyspnœa on exertion. This had appeared, on the average, 10-15 years after the onset of the bronchitic symptoms, but in a few instances it had been prominent from the very beginning of the illness. Considerable fluctuation in exercise tolerance occurred: cold weather, heavy fog, or minor respiratory infections all increased their dyspnœa; several of the patients with asthma, however, were most incapacitated in the summer. Since all patients were subject to exacerbations and remissions, it was difficult to classify with certainty the degree of their disability. In some, symptoms derived from congestive cardiac failure gradually merged with those from their pulmonary disease. Unless œdema had been noted by the patient, however, it was impossible from his symptoms to date the onset of cardiac failure accurately.

Certain other symptoms, less frequently encountered, were also directly ascribable to pulmonary disease. Four patients had episodes of mental confusion and drowsiness during attacks of acute bronchitis, at a time when they were intensely cyanotic. One had fainting spells precipitated by coughing (Charcot's laryngeal vertigo). Blood staining of the sputum was rare: hæmoptysis occurred in one patient, but here there was evidence of complicating bronchiectasis.

The majority of the patients were admitted to hospital in an acute exacerbation of bronchitis 
CIRCULATORY CHANGES IN SEVERE PULMONARY EMPHYSEMA

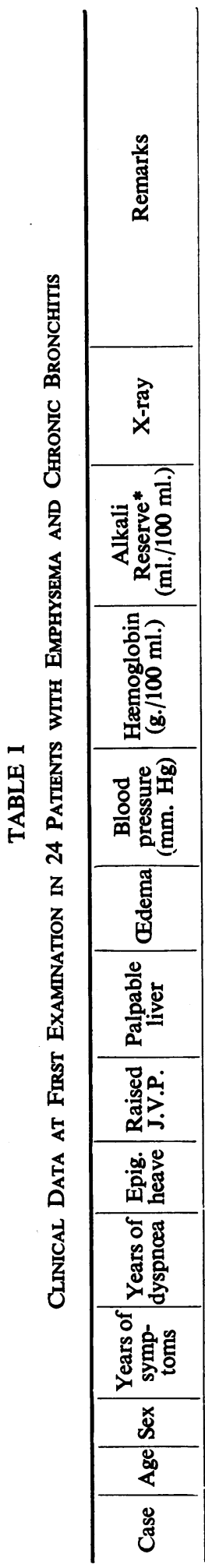

ชี

宙 宅

نे

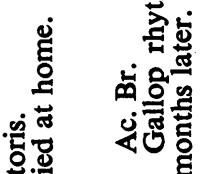

ن.

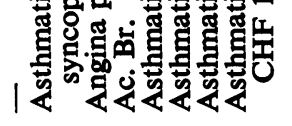

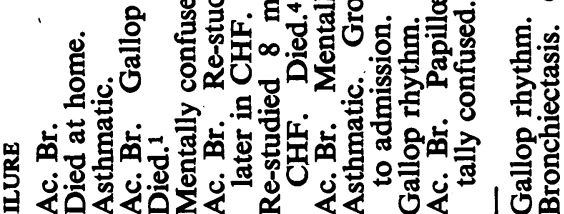

吾

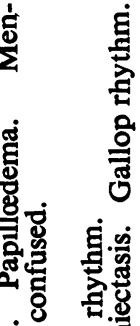

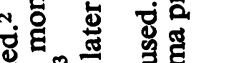

A

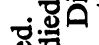

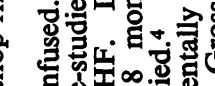

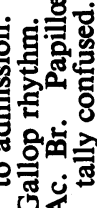

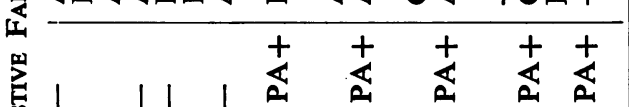

쀱미

兽

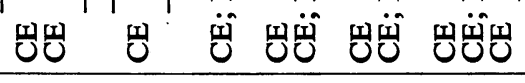

ธேேทัญッ์

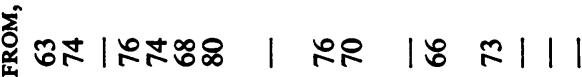

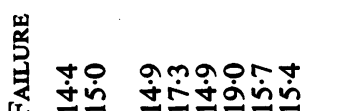

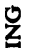

$\mathbf{z}$

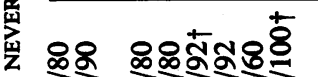

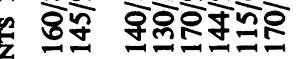

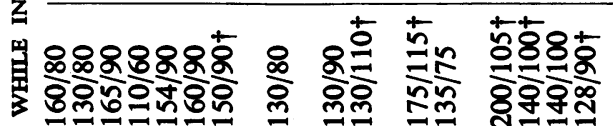

Z

00000000

索

09000m- $m$ to 0 t t-00

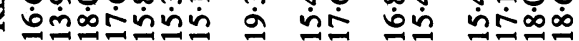
으

:

00 t+ooto

$0+++++0$ too to tot+

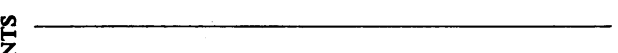

\& 00000 to 0 to to t+t+

00000000

窎

oo $0+0+++$

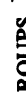

nn nnmoxm

bantuna $=$ nt -n mant

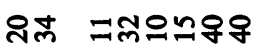

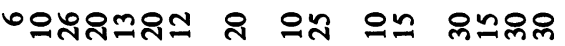

$\sum \sum \sum \sum \sum \sum \sum \amalg$

$\sum \sum \omega \sum \sum \Sigma \sum \sum \sum \omega \Sigma \sum \sum \Sigma \Sigma$

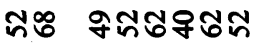

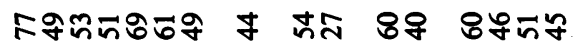

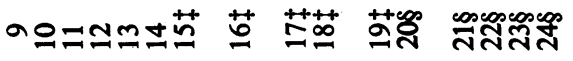

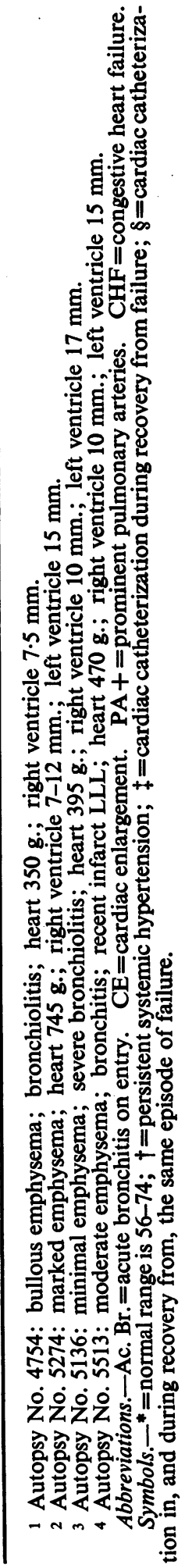

$\underline{\underline{m}}$ 
or in congestive heart failure, the latter usually being clearly associated with an acute respiratory infection. Several, however, entered for investigation in a relatively quiescent phase of their disease. All of the acutely ill patients were dyspnœic at rest and orthopnœic. Fever was not usually present. Twenty were observed to be cyanotic, and of these ten had early clubbing of the fingers. The findings on examination of the chest almost always followed a similar pattern. Movements of the thoracic cage were limited, and the antero-posterior diameter increased. On auscultation, there was often poor air entry, and loud rhonchi or coarse rales were audible throughout both lung fields; signs of bronchospasm were sometimes present. Abnormal findings restricted to localized areas of the lungs were unusual.

The anatomical changes in the thoracic cage associated with emphysema usually prevented any clinical estimation of the cardiac size. For the same reason, the heart sounds were faint over the præcordium and an accentuated pulmonary second sound could be heard only rarely. Forceful pulsation in the epigastrium, suggesting right ventricular hypertrophy, was present in half the patients. By auscultation in the epigastrium, it was occasionally possible to detect a gallop rhythm not audible at the apex. Fifteen patients had diastolic blood pressures of $90 \mathrm{~mm}$. $\mathrm{Hg}$ or higher on entry to the hospital, although these frequently fell to lower values within several days. Eight, however, had persistent systemic hypertension. All had a regular sinus rhythm with the exception of Case 18, who had transient episodes of auricular fibrillation. Signs of systemic venous congestion were present in 14 patients on admission. The presence of a palpable liver could not be considered a sign of venous congestion since many of the patients had a low diaphragm.

In general, the remainder of the physical examination added little of significance. In three patients, however, papillœdema was found to be present without localizing evidence of intracranial disease-a finding previously described in chronic bronchitis and emphysema (Simpson, 1948).

None of the routine clinical laboratory determinations was consistently abnormal. Hæmoglobin level was greater than $16 \mathrm{~g}$. per $100 \mathrm{ml}$. in 11 patients. The leucocyte count ranged on admission from 6000 to 28,000 ; it was sometimes normal even in the presence of undoubted bronchial infection. In the 16 in whom the alkali reserve was measured, it tended to be in the upper range of normal, and was increased in three.

Routine chest X-rays were usually interpreted as showing evidence of chronic bronchitis and emphysema. Cardiac enlargement was frequently seen in the presence of congestive heart failure (Fig. 1), but often it was difficult to assess the degree of specific chamber enlargement from the films, most of which were taken at the bedside. Prominent pulmonary arteries were observed in six patients.

Electrocardiographic findings of incomplete right bundle branch block or right ventricular hypertrophy were present in half the patients. A detailed analysis of the cardiograms is in preparation (Mounsey et al., unpublished).

In addition to the primary diagnosis of pulmonary emphysema and chronic bronchitis, a diagnosis of asthma was made in seven patients. Infection of a more acute nature was apparent in eight, designated in Table I by the term " acute bronchitis on entry."

Congestive heart failure was considered to be present in 16 patients on the basis of a raised jugular venous pressure with or without œdema. In general, patients in failure fell into two categories. Four (Cases 9, 15, 17, 20) had transient elevation of the venous pressure without œdema in direct association with their acute infection. The remaining twelve had congestive failure of a more chronic nature in which the raised jugular venous pressure was present for a longer period of time and was associated with some degree of œdema, varying from slight ankle œdema to gross anasarca.

In the acute phase of their disease, patients were treated with antibiotics, bronchodilators, and oxygen. It was of interest that three patients responded poorly to oxygen administration. Although their cyanosis disappeared, they became lethargic and semi-comatose, and improved only when removed from the oxygen tent. In Case 12, further study showed that oxygen inhalation was associated with a rise in arterial $\mathrm{CO}_{2}$ content and in cerebrospinal fluid pressure. 


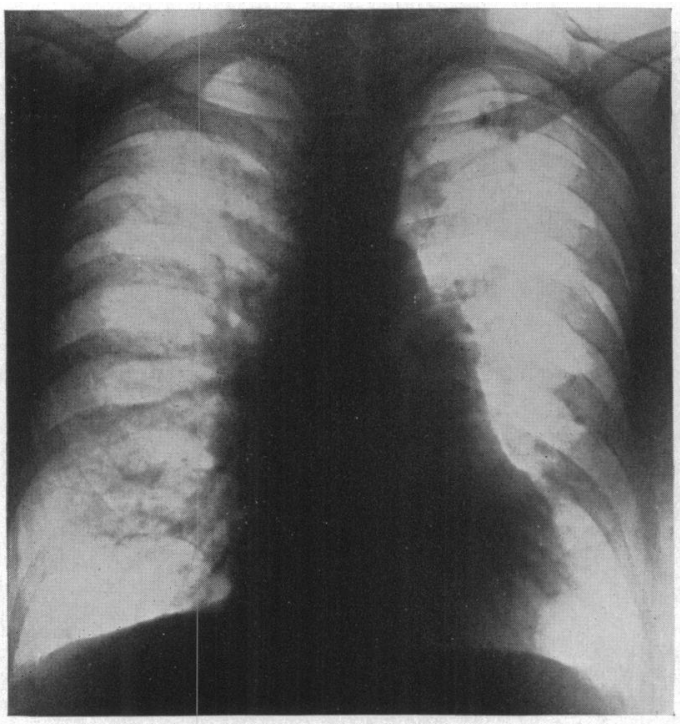

A

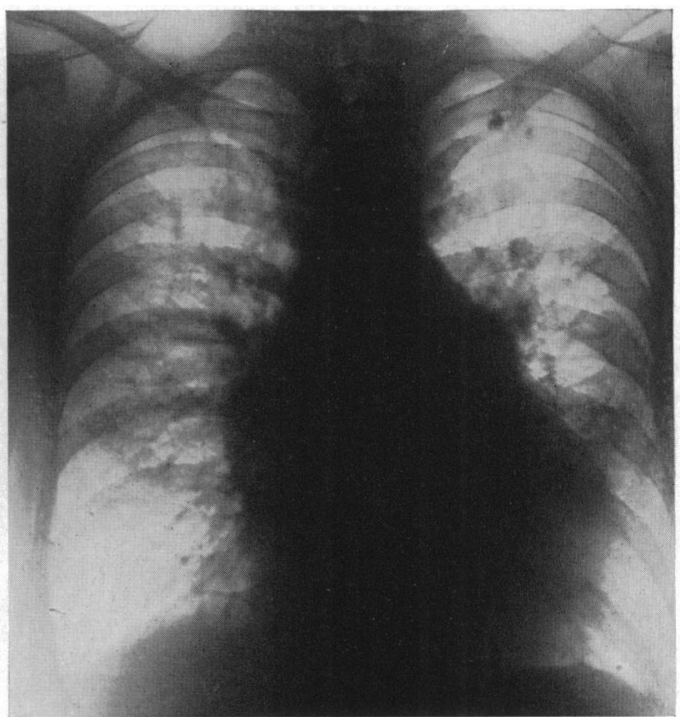

B

Fig. 1.-Teleradiogram of chest of Case 20. (A) Patient ambulant; no congestive phenomena. (B) Patient in gross heart failure during an attack of acute bronchitis. Both are two-metre, P-A films. With recovery the heart size was again comparable with (A).

Patients in cardiac failure received digitalis, mercurial diuretics, and a salt-poor diet. In only a few cases was venesection deemed necessary. The majority improved while in hospital and were able to return to their previous level of activity, with, however, persistence of their chronic symptoms; many have required readmission for further exacerbations of bronchitis or congestive failure. There have been six deaths in this series. Four patients, all with congestive failure, died while in hospital and pertinent data from their necropsies are included in Table I. Two others died at home within a few months of discharge from hospital.

\section{Respiratory Data}

The results of the respiratory studies are presented in Table II. The maximal breathing capacities were grossly reduced, ranging from 12 to 41 , with a mean of $23.3 \mathrm{litres} / \mathrm{min}$. The average residual air was 67 per cent of the total lung volume, as compared with the normal mean of 30 per cent; vital capacity was correspondingly decreased.

The ratio of the expected to the actual number of breaths required to achieve 90 per cent mixing in the lungs of a known amount of helium is expressed as the " 90 per cent mixing index " (Bates and Christie, 1950). The normal range in this laboratory is from $0.38-0.60$, with a mean of 0.51 (Briscoe, 1951). It will be seen that this was grossly reduced in every case in this series, never exceeding $0 \cdot 24$. The helium mixing method also permits estimation of that portion of the total lung volume ventilated mainly by diffusion. In normal subjects the volume of this " poorly ventilated space " may be as large as 0.4 litres, but usually is so small as to be incapable of measurement. In these emphysematous subjects, however, the mean value was 1.9 litres, with a range of from 1.1 to 4.5 litres.

As the result of congestive failure or of transient blockage of the airways with bronchial secretions, these findings may have been subject to some variation. We believe, however, that the data give a reasonable approximation to the average status of pulmonary function in each subject. The arterial oxygen saturations will be discussed with the circulatory findings. 
TABLE II

ResPiRATORY FUnCTION STUdies

\begin{tabular}{|c|c|c|c|c|c|c|}
\hline Case & $\begin{array}{l}\text { Maximal breathing } \\
\text { capacity } \\
\text { (litres a minute) }\end{array}$ & $\begin{array}{l}\text { Vital } \\
\text { capacity } \\
\text { (litres) }\end{array}$ & $\begin{array}{l}\text { Residual } \\
\text { air } \\
\text { (litres) }\end{array}$ & $\frac{\text { Residual air }}{\text { Total lung volume }} \underset{\text { (per cent) }}{ } \times 100$ & $\begin{array}{l}90 \% \text { mixing } \\
\text { index }\end{array}$ & $\begin{array}{c}\text { Volume poorly } \\
\text { ventilated } \\
\text { (litres) }\end{array}$ \\
\hline $\begin{array}{r}1 \\
2 \\
3 \\
4 \\
5 \\
6 \\
7 \\
8 \\
9 \\
10 \\
11 \\
12 \\
13 \\
14 \\
15 \\
16 \\
17 \\
18 \\
19 \\
20 \\
21 \\
22 \\
23 \\
24\end{array}$ & $\begin{array}{l}21 \cdot 6 \\
25 \cdot 2 \\
27.0 \\
12.4 \\
41.4 \\
13.8 \\
33.0 \\
-19.5 \\
14.0 \\
25 \cdot 2 \\
29 \cdot 1 \\
-10.0 \\
20.0 \\
22.0 \\
20.0 \\
24.0 \\
28.7 \\
16.2 \\
33.0 \\
22.8 \\
21.0 \\
27.0\end{array}$ & $\begin{array}{l}1.75 \\
1.45 \\
1.94 \\
1.50 \\
2.08 \\
1.33 \\
2.46 \\
2.18 \\
1.20 \\
1.83 \\
1.75 \\
1.65 \\
1.22 \\
2.26 \\
0.99 \\
2.02 \\
1.83 \\
2.61 \\
0.99 \\
1.35 \\
2.23 \\
1.85 \\
1.48 \\
1.63\end{array}$ & $\begin{array}{l}7 \cdot 63 * \\
3.55 \\
2.65 \\
4 \cdot 25 \\
3.52 \\
5.52 \\
3.94 \\
2.86 \\
3.20 \\
5.17 \\
2.32 \\
3.85 \\
2.00 \\
4.68 \\
3.90 \\
2.84 \\
2.95 \\
5.26 \\
2.20 \\
2.89 \\
2.85 \\
4.47 \\
1.87 \\
5.08\end{array}$ & $\begin{array}{l}82 \\
71 \\
58 \\
74 \\
63 \\
80 \\
62 \\
57 \\
73 \\
74 \\
57 \\
70 \\
62 \\
67 \\
80 \\
58 \\
62 \\
66 \\
69 \\
68 \\
56 \\
70 \\
56 \\
76\end{array}$ & $\begin{array}{l}0.18 \\
0.20 \\
0.16 \\
0.15 \\
0.22 \\
0.14 \\
0.09 \\
0.17 \\
0.10 \\
0.20 \\
0.15 \\
0.12 \\
0.08 \\
0.17 \\
0.17 \\
0.12 \\
0.16 \\
0.24 \\
0.13 \\
0.17 \\
0.23 \\
0.16 \\
0.10 \\
0.23\end{array}$ & $\begin{array}{l}4.50 \\
1.55 \\
1.60 \\
1.90 \\
1.10 \\
2.90 \\
2.20 \\
1.50 \\
2.00 \\
1.40 \\
2.00 \\
-1.20 \\
2.17 \\
1.20 \\
1.30 \\
3.20 \\
1.20 \\
1.30 \\
1.60 \\
2.35 \\
1.30 \\
1.95\end{array}$ \\
\hline $\begin{array}{l}\text { Mean } \\
\text { values } \\
\text { Normal } \\
\text { range }\end{array}$ & $\begin{array}{c}23 \cdot 3 \pm 7 \cdot 2 \\
55-145\end{array}$ & $\begin{array}{c}1 \cdot 73 \pm 0 \cdot 14 \\
-\end{array}$ & $\begin{array}{c}3 \cdot 73 \pm 1 \cdot 36 \\
-\end{array}$ & $\begin{array}{c}67 \cdot 1 \pm 8 \cdot 1 \\
16-40\end{array}$ & $\begin{array}{l}0.16 \pm 0.05 \\
0.38-0.60\end{array}$ & $\begin{array}{c}1.93 \pm 0.25 \\
0-0.4\end{array}$ \\
\hline
\end{tabular}

* This unusually high value was confirmed on several examinations.

\section{Hemodynamic Results}

(A) At Rest. The value obtained on catheterization of the right heart in patients studied at rest, on one occasion only, are shown in Table III. In each group, the cases are listed in ascending order of systolic right ventricular or pulmonary arterial pressures. Normal and mean values are given in Table $\mathrm{V}$.

There were eight patients in Group I, those who had never been in congestive heart failure; only Case 4 was acutely ill with bronchitis at the time of catheterization. The right ventricular systolic pressures ranged from 17 to $53 \mathrm{~mm}$. $\mathrm{Hg}$, half of the patients having normal pressures. The enddiastolic pressures were normal. Resting oxygen consumptions tended to be higher than reported basal values in emphysema (Taquini et al., 1948; Baldwin et al., 1949; Borden et al., 1950; Harvey et al., 1951). In seven patients the arterio-venous oxygen differences were within normal limits for these oxygen consumptions, but in one it was slightly increased. The cardiac indices ranged between 2.7 and 5.81 ./min./sq. metre. Oxygen saturations of the arterial blood in this group varied from 77 to 92 per cent. Two patients had raised hæmoglobin concentrations.

Eight patients were studied while they were in congestive heart failure (Group II). Two of these (Cases 15 and 16) had been studied on a previous admission when they were recovering from an earlier episode of failure. The right ventricular systolic pressure was significantly raised in every instance, ranging from 36 to $89 \mathrm{~mm}$. $\mathrm{Hg}$. The end-diastolic pressure was greater than $5 \mathrm{~mm}$. in 7 of the 8 patients; Case 10, whose diastolic pressure was only at the upper limit of normal, was, nevertheless, grossly œdematous at the time of study. Most resting oxygen consumptions were 
TABLE III

Circulatory Studies at Rest

\begin{tabular}{|c|c|c|c|c|c|c|c|c|c|}
\hline \multirow{2}{*}{ Case } & \multirow{2}{*}{$\begin{array}{l}\text { Body } \\
\text { surface } \\
\text { area } \\
\left(\mathrm{m}^{2}\right)\end{array}$} & \multirow{2}{*}{$\underset{\text { (per min.) }}{\text { Rate }}$} & \multicolumn{2}{|c|}{$\begin{array}{l}\text { Right ventricular } \\
\text { pressure }\end{array}$} & \multirow{2}{*}{$\begin{array}{c}\begin{array}{c}\text { Oxygen } \\
\text { consumption } \\
\left(\mathrm{ml} / / \mathrm{min} . / \mathrm{m}^{2}\right)\end{array} \\
-\end{array}$} & \multirow{2}{*}{$\begin{array}{c}\text { A-V } \\
\text { oxygen } \\
\text { difference } \\
\text { (ml./litre) }\end{array}$} & \multirow{2}{*}{$\begin{array}{c}\text { Cardiac } \\
\text { index } \\
\left(1 / \mathrm{min} / \mathrm{m}^{2}\right)\end{array}$} & \multirow{2}{*}{$\begin{array}{c}\text { Hæmoglobin } \\
(\mathbf{g} . / 100 \mathrm{ml} .)\end{array}$} & \multirow{2}{*}{$\begin{array}{c}\text { Arterial } \\
\text { saturation } \\
\text { (per cent) }\end{array}$} \\
\hline & & & $\begin{array}{l}\text { Systolic } \\
\text { (mm. Hg) }\end{array}$ & $\begin{array}{l}\text { End- } \\
\text { diastolic } \\
(\mathrm{mm} . \mathrm{Hg})\end{array}$ & & & & & \\
\hline
\end{tabular}

\begin{tabular}{l|l}
1 & 1.64 \\
2 & 1.91 \\
3 & 1.56 \\
4 & 1.67 \\
5 & 1.87 \\
6 & 1.58 \\
7 & 1.9 \\
8 & 1.9 \\
\hline
\end{tabular}

\begin{tabular}{l|r|l|l|}
1.64 & 75 & $17^{*}$ & \\
1.91 & 81 & 26 \\
1.56 & 88 & 30 \\
1.67 & 100 & $31^{*}$ & \\
1.87 & 83 & 34 & \\
1.58 & 100 & $42^{*}$ & \\
1.97 & 79 & 46 & \\
1.92 & 100 & 53 &
\end{tabular}

\begin{tabular}{|c|c|c|c|c|c|}
\hline \multicolumn{6}{|c|}{ Group I-Not in Failure } \\
\hline $\begin{array}{l}1 \dagger \\
5 \\
2 \\
-1 \dagger \\
5 \\
3 \dagger \\
2 \\
5\end{array}$ & $\begin{array}{l}183 \\
174 \\
226 \\
209 \\
182 \\
207 \\
151 \\
170\end{array}$ & $\begin{array}{l}66.0 \\
38.0 \\
39.0 \\
46.7 \\
35.2 \\
44.6 \\
56.0 \\
47.5\end{array}$ & $\begin{array}{l}2 \cdot 8 \\
4 \cdot 6 \\
5 \cdot 8 \\
4.5 \\
5.2 \\
4.6 \\
2.7 \\
3.6\end{array}$ & $\begin{array}{l}14.4 \\
15.0 \\
14.9 \\
17.3 \\
14.9 \\
19.0 \\
15.7 \\
15.4\end{array}$ & $\begin{array}{l}91 \\
90 \\
85 \\
82 \\
92 \\
89\end{array}$ \\
\hline
\end{tabular}

\begin{tabular}{r|r|r|r}
9 & 1.64 & 79 & 36 \\
11 & 1.86 & 90 & 40 \\
12 & 1.56 & 94 & 4 \\
13 & 1.64 & 97 & 47 \\
14 & 1.48 & 94 & 60 \\
15 & 1.78 & 70 & 66 \\
16 & 1.54 & 115 & 66 \\
& 100 & 89
\end{tabular}

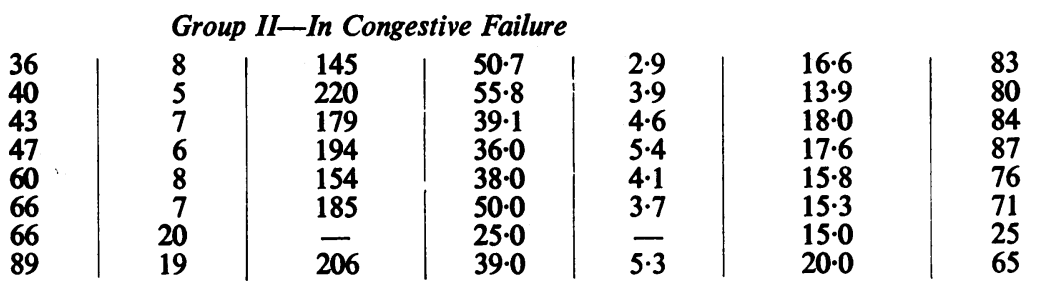

\begin{tabular}{|c|c|c|c|c|c|c|c|c|c|}
\hline & \multicolumn{9}{|c|}{ Group III-Recovering from Failure } \\
\hline $\begin{array}{l}15 \\
17 \\
16 \\
18 \\
19\end{array}$ & $\begin{array}{l}1.65 \\
1.72 \\
1.48 \\
1.65 \\
1.43\end{array}$ & $\begin{array}{c}102 \\
88 \\
86 \\
130 \ddagger \\
72\end{array}$ & $\begin{array}{l}21 \\
30 \\
41 \\
42 \\
49^{*}\end{array}$ & $\begin{array}{c}-2 \\
-1 \\
4 \\
6 \\
-3 \dagger\end{array}$ & $\begin{array}{l}151 \\
151 \\
216 \\
167 \\
150\end{array}$ & $\begin{array}{l}-\overline{37.4} \\
34.0 \\
59.0 \\
28.0\end{array}$ & $\begin{array}{l}\overline{4 \cdot 0} \\
6.4 \\
2 \cdot 8 \\
5 \cdot 4\end{array}$ & $\begin{array}{l}15.1 \\
15.4 \\
19.3 \\
17.6 \\
16.8\end{array}$ & $\begin{array}{l}79 \\
82 \\
74 \\
74 \\
83\end{array}$ \\
\hline
\end{tabular}

Symbols: ${ }^{*}=$ systolic pulmonary arterial pressure. $\dagger=$ mean right auricular pressure. $\ddagger=$ auricular fibrillation.

again found to be raised. Despite the presence of congestive failure, none of the arterio-venous oxygen differences was outside the normal range. On the whole, the cardiac indices were similar to those found in Group I. The arterial oxygen saturations ranged from 25 to 87 per cent; the strikingly low value of 25 per cent in Case 15 was obtained when he was terminally ill, twenty-six hours before death. In four patients, the hæmoglobin concentration was greater than $16 \mathrm{~g}$. per $100 \mathrm{ml}$., reaching $20 \mathrm{~g}$. in one instance.

Group III contains five patients studied during recovery from congestive heart failure. The systolic pressures were normal in two of these, and moderately raised in the remaining three. With one exception, the end-diastolic pressures were normal. The resting oxygen consumptions were comparable with those of the two previous groups. One patient had an arterio-venous oxygen difference slightly lower than normal. The cardiac indices varied from 2.8 to $6.4 \mathrm{l} / \mathrm{min}$./sq. metre. Arterial oxygen saturations ranged from 74 to 83 per cent. Three patients had hæmoglobin concentrations greater than $16 \mathrm{~g}$. per $100 \mathrm{ml}$.

In Table IV are presented the data obtained in five patients who were investigated both during failure and recovery (Cases 20-24). When first studied, their findings on catheterization were similar to those in Group II. At the time of the second study, two to seven weeks later, the right ventricular pressures had fallen in every instance from their previously high levels, and in two cases they were now normal (Fig. 2). The raised end-diastolic pressures had all returned to normal, and the low 
levels of arterial oxygen saturation had risen considerably. Changes in the resting oxygen consumptions and the arterio-venous oxygen differences were not always in the same direction. Consequently, on recovery, the cardiac index in three patients was higher and in two was lower than it had been during failure. In three patients with evidence of polycythæmia, the hæmoglobin value fell on recovery, but did not return to normal.

The summary of the results obtained on cardiac catheterization in the three groups of patients is shown in Table V, where mean values are listed. For the calculation of these mean values the data in congestive failure from Table IV have been added to Group II in Table III, while recovery figures from Table IV were added to Group III in Table III. No great differences could be shown between the patients in Group I, who had never been in failure, and those in Group III, who were

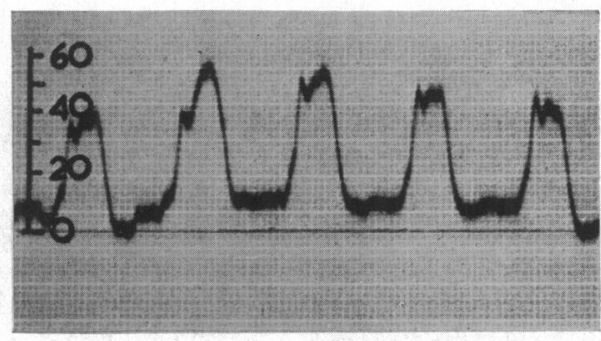

A

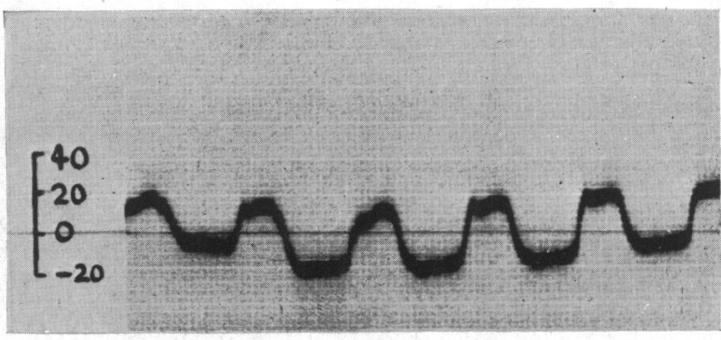

B

FIG. 2.-Right ventricular pressure tracings showing a reduction of resting pressure with recovery from congestive cardiac failure. Case 20 (A) In failure the pressure was $43 / 8 \mathrm{~mm}$. $\mathrm{Hg}$; (B) Two weeks later during recovery from failure it was $19 /-5 \mathrm{~mm} . \mathrm{Hg}$.

recovering from failure. Both groups, however, differed from normal subjects in several respects: their average systolic right ventricular pressures were moderately raised; resting oxygen consumptions were increased; and there was arterial oxygen unsaturation. Arterio-venous oxygen differences and cardiac indices were normal. It is apparent that three significant features distinguished the patients in Group II, who were in congestive failure at the time of investigation, from the others: the average right ventricular pressures, both systolic and end-diastolic, were considerably raised above those found in Groups I and II, and there was an even more severe degree of arterial un-

TABLE IV

Circulatory Studies at Rest in Five Patients in Failure and during Recovery

\begin{tabular}{|c|c|c|c|c|c|c|c|c|c|c|}
\hline \multirow{2}{*}{ Case } & & \multirow{2}{*}{$\begin{array}{l}\text { Body } \\
\text { surface } \\
\text { area } \\
\left(\mathrm{m}^{2}\right)\end{array}$} & \multirow{2}{*}{$\begin{array}{l}\text { Rate } \\
\text { (per } \\
\text { min.) }\end{array}$} & \multicolumn{2}{|c|}{$\begin{array}{l}\text { Rt. ventricular } \\
\text { pressure }\end{array}$} & \multirow{2}{*}{$\begin{array}{c}\text { Oxygen } \\
\text { consump- } \\
\text { tion } \\
\left(\mathrm{ml} . / \mathrm{min} . / \mathrm{m}^{2}\right.\end{array}$} & \multirow{2}{*}{$\begin{array}{c}\text { A-V } \\
\text { oxygen } \\
\text { difference } \\
\text { (ml./litre) }\end{array}$} & \multirow{2}{*}{$\begin{array}{c}\text { Cardiac } \\
\text { index } \\
\left(1 / \mathrm{min} . / \mathrm{m}^{2}\right.\end{array}$} & \multirow{2}{*}{$\begin{array}{c}\text { Hæmo- } \\
\text { globin } \\
\text { (g./100 ml.) }\end{array}$} & \multirow{2}{*}{$\begin{array}{c}\text { Arterial } \\
\mathbf{O}_{2} \text { satura- } \\
\text { tion } \\
(\text { per cen } \mathrm{t})\end{array}$} \\
\hline & & & & $\underset{\text { Hg) }}{\text { Systolic }}$ & $\left|\begin{array}{c}\text { End- } \\
\text { diastolic } \\
(\mathrm{mm} . \mathrm{Hg})\end{array}\right|$ & & & & & \\
\hline 20 & $\begin{array}{l}\text { With C.H.F. } \\
2 \text { weeks later }\end{array}$ & $\begin{array}{l}1 \cdot 86 \\
1.86\end{array}$ & $\begin{array}{l}83 \\
84\end{array}$ & $\begin{array}{l}43 \\
19\end{array}$ & $\frac{8}{-5}$ & $\begin{array}{l}148 \\
141\end{array}$ & $\begin{array}{l}43 \cdot 4 \\
48 \cdot 0\end{array}$ & $\begin{array}{l}3 \cdot 4 \\
2 \cdot 9\end{array}$ & $\begin{array}{l}15 \cdot 4 \\
15 \cdot 4\end{array}$ & $\begin{array}{l}68 \\
87\end{array}$ \\
\hline 21 & $\begin{array}{l}\text { With C.H.F. } \\
2 \text { weeks later }\end{array}$ & $\begin{array}{l}1 \cdot 71 \\
1 \cdot 60\end{array}$ & $\begin{array}{r}100 \\
70\end{array}$ & $\begin{array}{l}63 \\
20\end{array}$ & $\begin{array}{r}14 \\
0\end{array}$ & $\begin{array}{l}206 \\
177\end{array}$ & $\begin{array}{l}46 \cdot 0 \\
45 \cdot 0\end{array}$ & $\begin{array}{l}4 \cdot 5 \\
3 \cdot 9\end{array}$ & $\begin{array}{l}15 \cdot 4 \\
15 \cdot 4\end{array}$ & $\begin{array}{l}49 \\
81\end{array}$ \\
\hline 22 & $\begin{array}{l}\text { With C.H.F. } \\
7 \text { weeks later }\end{array}$ & $\begin{array}{l}1.69 \\
1.65\end{array}$ & $\begin{array}{l}88 \\
79\end{array}$ & $\begin{array}{l}71 \\
43\end{array}$ & $\begin{array}{l}9 \\
0\end{array}$ & $\begin{array}{l}186 \\
232\end{array}$ & $\begin{array}{l}47 \cdot 7 \\
35 \cdot 7\end{array}$ & $\begin{array}{l}3 \cdot 9 \\
6 \cdot 5\end{array}$ & $\begin{array}{l}17 \cdot 1 \\
16 \cdot 3\end{array}$ & $\begin{array}{l}73 \\
84\end{array}$ \\
\hline 23 & $\begin{array}{l}\text { With C.H.F. } \\
2 \text { weeks later }\end{array}$ & $\begin{array}{l}1 \cdot 46 \\
1 \cdot 48\end{array}$ & $\begin{array}{r}100 \\
77\end{array}$ & $\begin{array}{l}71 \\
51\end{array}$ & $\begin{array}{r}11 \\
4\end{array}$ & $\begin{array}{l}184 \\
225\end{array}$ & $\begin{array}{l}35 \cdot 9 \\
34 \cdot 2\end{array}$ & $\begin{array}{l}5 \cdot 1 \\
6 \cdot 6\end{array}$ & $\begin{array}{l}18 \cdot 0 \\
16 \cdot 9\end{array}$ & $\begin{array}{l}71 \\
84\end{array}$ \\
\hline 24 & $\begin{array}{l}\text { With C.H.F. } \\
4 \text { weeks later }\end{array}$ & $\begin{array}{l}1 \cdot 76 \\
1 \cdot 57\end{array}$ & $\begin{array}{l}94 \\
97\end{array}$ & $\begin{array}{l}83 \\
46\end{array}$ & $\begin{array}{r}18 \\
4\end{array}$ & $\begin{array}{l}172 \\
245\end{array}$ & $\begin{array}{l}55 \cdot 9 \\
38 \cdot 2\end{array}$ & $\begin{array}{l}3 \cdot 1 \\
6 \cdot 4\end{array}$ & $\begin{array}{l}18 \cdot 6 \\
16 \cdot 2\end{array}$ & $\begin{array}{l}82 \\
92\end{array}$ \\
\hline
\end{tabular}


TABLE V

Mean Values of the Circulatory Studies at Rest in all Patients

\begin{tabular}{|c|c|c|c|c|c|c|c|c|}
\hline & \multirow{2}{*}{$\begin{array}{c}\text { Rate } \\
\text { (per min.) }\end{array}$} & \multicolumn{2}{|c|}{ Rt. ventricular pressure } & \multirow{2}{*}{$\begin{array}{c}\text { Oxygen } \\
\text { consump- } \\
\text { tion } \\
\left(\mathrm{ml} . / \mathrm{min} . / \mathrm{m}^{2}\right)\end{array}$} & \multirow{2}{*}{$\begin{array}{c}\text { A-V oxygen } \\
\text { difference } \\
\text { (ml./litre) }\end{array}$} & \multirow{2}{*}{$\begin{array}{c}\text { Cardiac } \\
\text { index } \\
\left(1 / \mathrm{min}^{\prime} / \mathrm{m}^{2}\right)\end{array}$} & \multirow{2}{*}{$\begin{array}{c}\text { Hæmo- } \\
\text { globin } \\
\text { (g. } / 100 \mathrm{ml} \text {.) }\end{array}$} & \multirow{2}{*}{$\begin{array}{l}\text { Arterial } \mathbf{O}_{2} \\
\text { saturation } \\
\text { (per cent) }\end{array}$} \\
\hline & & $\begin{array}{l}\text { Systolic } \\
(\mathrm{mm} . \mathrm{Hg})\end{array}$ & $\begin{array}{l}\text { Diastolic } \\
(\mathrm{mm} . \mathrm{Hg})\end{array}$ & & & & & \\
\hline $\begin{array}{l}\text { Group I } \\
\text { (8 cases) }\end{array}$ & $88 \cdot 3 \pm 10 \cdot 4 *$ & $34 \cdot 9 \pm 11 \cdot 7$ & $2 \cdot 8 \pm 2 \cdot 2$ & $187 \cdot 8 \pm 24 \cdot 5$ & $46 \cdot 6 \pm 10 \cdot 2$ & $4 \cdot 2 \pm 1 \cdot 1$ & $15 \cdot 8 \pm 1 \cdot 6$ & $86 \cdot 0 \pm 5 \cdot 4$ \\
\hline$\underset{\text { (13 cases) }}{\text { Group II }}$ & $92 \cdot 6 \pm 11 \cdot 2$ & $59 \cdot 8 \pm 16 \cdot 8$ & $10 \cdot 8 \pm 5 \cdot 2$ & $181 \cdot 6 \pm 23 \cdot 7$ & $43 \cdot 3 \pm 8 \cdot 9$ & $4 \cdot 2 \pm 0 \cdot 8$ & $16 \cdot 7 \pm 1 \cdot 4$ & $70 \cdot 3 \pm 17 \cdot 0 \dagger$ \\
\hline $\begin{array}{c}\text { Group III } \\
(10 \text { cases })\end{array}$ & $88 \cdot 5 \pm 17 \cdot 8$ & $36 \cdot 2 \pm 12 \cdot 5$ & $0.7 \pm 3.6$ & $185 \cdot 5 \pm 39 \cdot 8$ & $39 \cdot 9 \pm 9 \cdot 3$ & $5 \cdot 0 \pm 1 \cdot 6$ & $16 \cdot 4 \pm 1 \cdot 8$ & $82 \cdot 0 \pm 5 \cdot 5$ \\
\hline $\begin{array}{l}\text { Normal } \\
\text { range }\end{array}$ & $60-90$ & $15-30$ & $-5-+5$ & $\begin{array}{l}100-145 \\
\text { (Basal) }\end{array}$ & $31-61$ & $>2.5$ & $\begin{array}{c}14-17 \\
\text { Mean 14.8) }\end{array}$ & $95-97$ \\
\hline
\end{tabular}

* Standard deviation of the mean.

$\dagger$ If the value of 25 per cent in Case 15 is omitted, this figure $=74 \cdot 1 \pm 10 \cdot 4$.

saturation. In all the groups, the average hæmoglobin concentration tended to be higher than normal; the small difference between Group I and Groups II and III was statistically significant, indicating increased hæmoglobin concentrations in the patients in, or recovering from, congestive heart failure.

(B) Effects of Oxygen. Oxygen was administered to 14 patients during cardiac catheterization. The results are given in Table VI, where patients are listed in the order of their control level of arterial saturation.

All except one of them were able to achieve normal oxygen saturations. The cardiac rate tended to slow, a reaction previously reported in emphysematous subjects (Taquini et al., 1948). Deviations from the previous control figures of the right ventricular systolic pressure occurred in almost every case, but these were usually of doubtful significance since similar fluctuations in pressure were observed without relation to giving oxygen. Three patients (Cases 3,14, and 16), however, showed a sustained fall in pressure throughout the administration of oxygen, which was of greater magnitude than any spontaneous fluctuation observed: in two of these, the end-diastolic pressure also fell.

The oxygen consumption during the breathing of pure oxygen was measured in six patients only. In five, this spirometric value was lower than the control determination derived from analysis of expired air. Whether this represented a true difference in oxygen uptake or was primarily the result of the difference in techniques was undetermined.

Arterio-venous oxygen differences were measured in all cases. If changes of more than $5 \mathrm{ml}$. per litre (0.5 vol. \%) be considered significant (Bayliss et al., 1950), then in seven there was a decrease, in three an increase, and in four no change. It was of interest that the three patients in whom it rose were those in whom a fall in right ventricular pressure was observed. Since oxygen consumptions were not obtained in two of these, cardiac outputs could not be calculated, but it is probable that the rise in arterio-venous oxygen difference indicated a fall in cardiac output. In Case 14, in whom the output was actually determined, it did, indeed, fall from 7.0 to 4.7 litres a minute. The cardiac outputs measured in five other subjects did not seem to be associated with changes in right ventricular pressure. Although the cardiac output fell in Cases 6 and 24 without a change in pressure, in these instances the fall was primarily determined by a decrease in oxygen uptake, rather than by a change in the arterio-venous oxygen difference.

There was a rise in the peripheral arterial pressure in all nine patients in whom it was measured. In only five, however, could this change be considered significant, in view of the spontaneous fluctuations observed. An increase in peripheral resistance in normal subjects breathing oxygen has been previously reported (Whitehorn et al., 1946). 
TABLE VI

EFFECTS OF OXYGEN

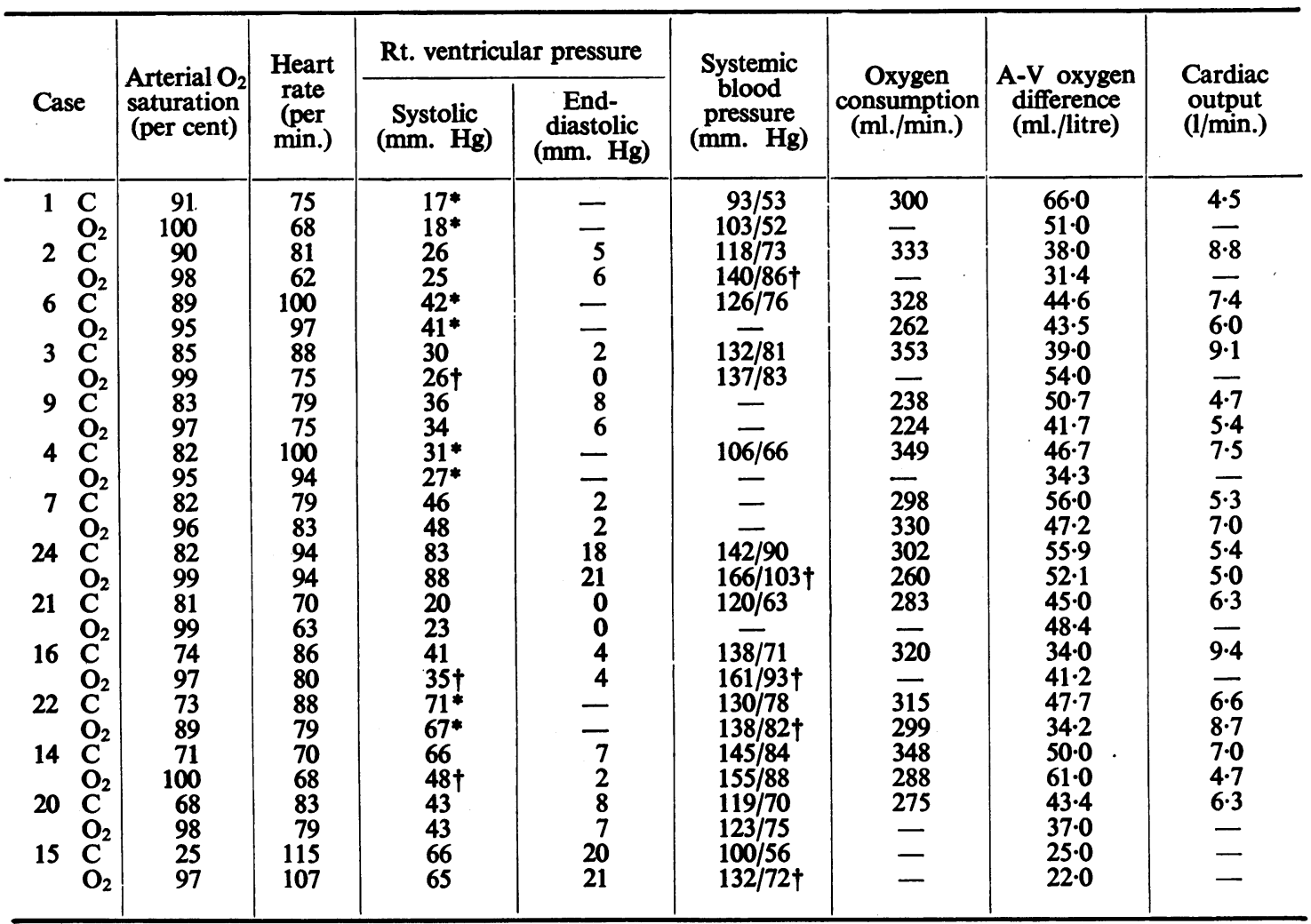

$\mathrm{C}=$ control values at rest.

*=systolic pulmonary arterial pressure.

$\mathrm{O}_{2}=$ determinations during the administration of oxygen.

$\dagger=$ change considered significant.

(C) Effects of Exercise. The effects of exercise were studied in five patients. In all the right ventricular systolic pressure rose significantly above the resting value (Table VII). The end-diastolic pressure, when initially normal, showed a slight fall. In one of the two patients in congestive failure when exercised, the end-diastolic pressure rose sharply from 6 to $15 \mathrm{~mm} . \mathrm{Hg}$; in the other, who was only mildly exercised, there was no change in this value. The cardiac output showed a substantial rise in the two patients in whom it was measured. The arterial oxygen saturation, determined in three patients, rose slightly during exercise in two.

(D) Effects of Cardiac Glycosides. The effects of cardiac glycosides were studied in five patients, of whom four received digoxin and one ouabain. All of the patients were in clinical congestive failure, with the exception of Case 8. This patient had no evidence of systemic venous congestion, but did have diastolic gallop rhythm and cardiac enlargement: it was of interest that signs of congestive failure did not appear until 18 months later.

Values listed in Table VIII are the final ones observed before withdrawal of the catheter. The predominant changes after digitalis consisted of a slight rise in the right ventricular systolic pressure and a fall in the end-diastolic pressure. In three patients there was moderate slowing of the cardiac rate, while there was no change in the other two. Neither the direction nor the magnitude of change in the cardiac index could be considered significant in any case. In three patients the systolic arterial blood pressure rose slightly. 
TABLE VII

EFFECTS OF EXERCISE

\begin{tabular}{|c|c|c|c|c|c|c|c|c|c|}
\hline \multirow[b]{2}{*}{ Case } & & \multirow[b]{2}{*}{$\begin{array}{c}\text { Rate } \\
\text { (per min.) }\end{array}$} & \multicolumn{2}{|c|}{$\begin{array}{l}\text { Rt. ventricular } \\
\text { pressure }\end{array}$} & \multirow{2}{*}{$\begin{array}{l}\text { Systemic } \\
\text { blood } \\
\text { pressure } \\
(\mathrm{mm} . \mathbf{H g})\end{array}$} & \multirow{2}{*}{$\begin{array}{c}\text { Oxygen } \\
\text { consump- } \\
\text { tion } \\
\text { (ml./min.) }\end{array}$} & \multirow{2}{*}{$\begin{array}{c}\text { A-V } \\
\text { oxygen } \\
\text { difference } \\
\text { (ml./litre) }\end{array}$} & \multirow{2}{*}{$\begin{array}{l}\text { Cardiac } \\
\text { output } \\
\text { (1/min.) }\end{array}$} & \multirow{2}{*}{$\begin{array}{l}\text { Arterial } \mathbf{O}_{2} \\
\text { saturation } \\
\text { (per cent) }\end{array}$} \\
\hline & & & $\begin{array}{c}\text { Systolic } \\
(\mathrm{mm} . \mathrm{Hg})\end{array}$ & $\begin{array}{c}\text { End- } \\
\text { diastolic } \\
\text { (mm. Hg) }\end{array}$ & & & & & \\
\hline 3 & $\begin{array}{l}\text { Control } \\
\text { Exercise }\end{array}$ & $\begin{array}{l}83 \\
97\end{array}$ & $\begin{array}{l}32 \\
65\end{array}$ & $\begin{array}{l}3 \\
1\end{array}$ & $\begin{array}{l}130 / 76 \\
150 / 89\end{array}$ & - & 二 & 二 & $\begin{array}{l}87 \\
87\end{array}$ \\
\hline 5 & $\begin{array}{l}\text { Control } \\
\text { Exercise }\end{array}$ & $\begin{array}{l}83 \\
97\end{array}$ & $\begin{array}{l}34 \\
41\end{array}$ & $\begin{array}{l}5 \\
2\end{array}$ & $\begin{array}{l}170 / 68 \\
188 / 75\end{array}$ & $\begin{array}{l}340 \\
888\end{array}$ & $\begin{array}{l}35 \cdot 2 \\
38 \cdot 4\end{array}$ & $\begin{array}{r}9 \cdot 7 \\
22 \cdot 9\end{array}$ & $\begin{array}{l}92 \\
96\end{array}$ \\
\hline 11 & $\begin{array}{l}\text { Control } \\
\text { Exercise }\end{array}$ & $\begin{array}{r}94 \\
100\end{array}$ & $\begin{array}{l}43 \\
50\end{array}$ & $\begin{array}{l}7 \\
7\end{array}$ & 二 & 二 & 二 & 二 & - \\
\hline 12 & $\begin{array}{l}\text { Control } \\
\text { Exercise }\end{array}$ & $\begin{array}{r}97 \\
100\end{array}$ & $\begin{array}{l}47 \\
76\end{array}$ & $\begin{array}{r}6 \\
15\end{array}$ & $\begin{array}{l}150 / 83 \\
182 / 91\end{array}$ & $\begin{array}{l}317 \\
553\end{array}$ & $\begin{array}{l}36 \cdot 0 \\
40 \cdot 4\end{array}$ & $\begin{array}{l}8 \cdot 8 \\
13 \cdot 6\end{array}$ & $\begin{array}{l}87 \\
90\end{array}$ \\
\hline 22 & $\begin{array}{l}\text { Control } \\
\text { Exercise }\end{array}$ & $\begin{array}{r}79 \\
100\end{array}$ & $\begin{array}{l}43 \\
60\end{array}$ & $\begin{array}{r}0 \\
-1\end{array}$ & - & 二 & 二 & - & - \\
\hline
\end{tabular}

TABLE VIII

EfFects of Cardiac Glycosides

\begin{tabular}{|c|c|c|c|c|c|c|c|c|}
\hline \multirow{2}{*}{ Case } & \multirow{2}{*}{ Drug } & \multirow{2}{*}{$\begin{array}{l}\text { Dose } \\
\text { (mg.) }\end{array}$} & \multirow{2}{*}{$\underset{\text { (min.) }}{\text { Time }}$} & \multirow{2}{*}{$\begin{array}{r}\text { Heart rate } \\
\text { (per min.) }\end{array}$} & \multicolumn{2}{|c|}{ Rt. ventricular pressure } & \multirow{2}{*}{$\begin{array}{c}\text { Systemic blood } \\
\text { pressure } \\
\text { (mm. Hg) }\end{array}$} & \multirow{2}{*}{$\begin{array}{l}\text { Cardiac } \\
\text { output } \\
\text { (1/min.) }\end{array}$} \\
\hline & & & & & $\begin{array}{l}\text { Systolic } \\
(\mathbf{m m} . \mathbf{H g})\end{array}$ & $\begin{array}{c}\text { End-diastolic } \\
\text { (mm. Hg) }\end{array}$ & & \\
\hline 10 & $\begin{array}{l}\text { Control } \\
\text { Digoxin }\end{array}$ & $\overline{1.5}$ & $\overline{30}$ & $\begin{array}{l}90 \\
80\end{array}$ & $\begin{array}{l}40 \\
43\end{array}$ & $\begin{array}{l}5 \\
1\end{array}$ & $130 / 80$ & $\begin{array}{l}7.2 \\
7.8\end{array}$ \\
\hline 13 & $\begin{array}{l}\text { Control } \\
\text { Digoxin }\end{array}$ & $\overline{1 \cdot 0}$ & $\overline{24}$ & $\begin{array}{l}94 \\
94\end{array}$ & $\begin{array}{l}60 \\
69\end{array}$ & $\begin{array}{l}8 \\
6\end{array}$ & $\begin{array}{l}150 / 78 \\
170 / 84\end{array}$ & $\begin{array}{l}6 \cdot 0 \\
5 \cdot 4\end{array}$ \\
\hline 14 & $\begin{array}{l}\text { Control } \\
\text { Digoxin }\end{array}$ & $\overline{1 \cdot 5}$ & $\overline{48}$ & $\begin{array}{l}70 \\
65\end{array}$ & $\begin{array}{l}66 \\
69\end{array}$ & $\begin{array}{l}7 \\
3\end{array}$ & $\begin{array}{l}145 / 84 \\
150 / 88\end{array}$ & $\begin{array}{l}7 \cdot 0 \\
7 \cdot 1\end{array}$ \\
\hline 20 & $\begin{array}{l}\text { Control } \\
\text { Digoxin }\end{array}$ & $\overline{1.0}$ & $\overline{53}$ & $\begin{array}{l}79 \\
79\end{array}$ & $\begin{array}{l}43 \\
46\end{array}$ & $\begin{array}{l}7 \\
4\end{array}$ & $\begin{array}{l}123 / 79 \\
123 / 75\end{array}$ & $\begin{array}{l}7.4 \\
6.7\end{array}$ \\
\hline 8 & $\begin{array}{l}\text { Control } \\
\text { Ouabain }\end{array}$ & $\overline{0.75}$ & $\overline{44}$ & $\begin{array}{r}100 \\
88\end{array}$ & $\begin{array}{l}53 \\
57\end{array}$ & $\begin{array}{l}5 \\
3\end{array}$ & $\begin{array}{l}180 / 105 \\
190 / 95\end{array}$ & $\begin{array}{l}6 \cdot 8 \\
6 \cdot 1\end{array}$ \\
\hline
\end{tabular}

Discussion

Pulmonary Function Studies. The pulmonary function studies confirmed the clinical impression of a severe degree of ventilatory disability in all cases. In the several where there were repeated examinations of the same patient both in, and during recovery from, congestive failure, only moderate deviations from the status indicated in Table I were observed, and these were reflected primarily by improvement in the maximal breathing capacity and the 90 per cent mixing index; only slight variations were noted in the residual air percentage. Ferrer et al. (1950) had similar findings in five patients with chronic cor pulmonale in failure. The difference in time between the pulmonary and hæmodynamic investigations made it difficult to correlate these measurements closely. It was evident, however, that the pulmonary determinations in the eight patients who 
had never been in congestive failure did not differ significantly from those found in the patients who had developed this complication. In like fashion the cardiac failure group of Harvey et al. (1951) could not be distinguished on the rasis of respiratory function from the group.with severe emphysema alone.

Pulmonary Hypertension. The results obtained from cardiac catheterization revealed that the primary difference in the hæmodynamic status of the three groups of patients was the level of systolic right ventricular pressure. ${ }^{*}$ It would seem necessary, therefore, to discuss briefly certain of the factors contributing to alterations of pressure in the pulmonary circulation-a subject that has recently been reviewed by Cournand (1950).

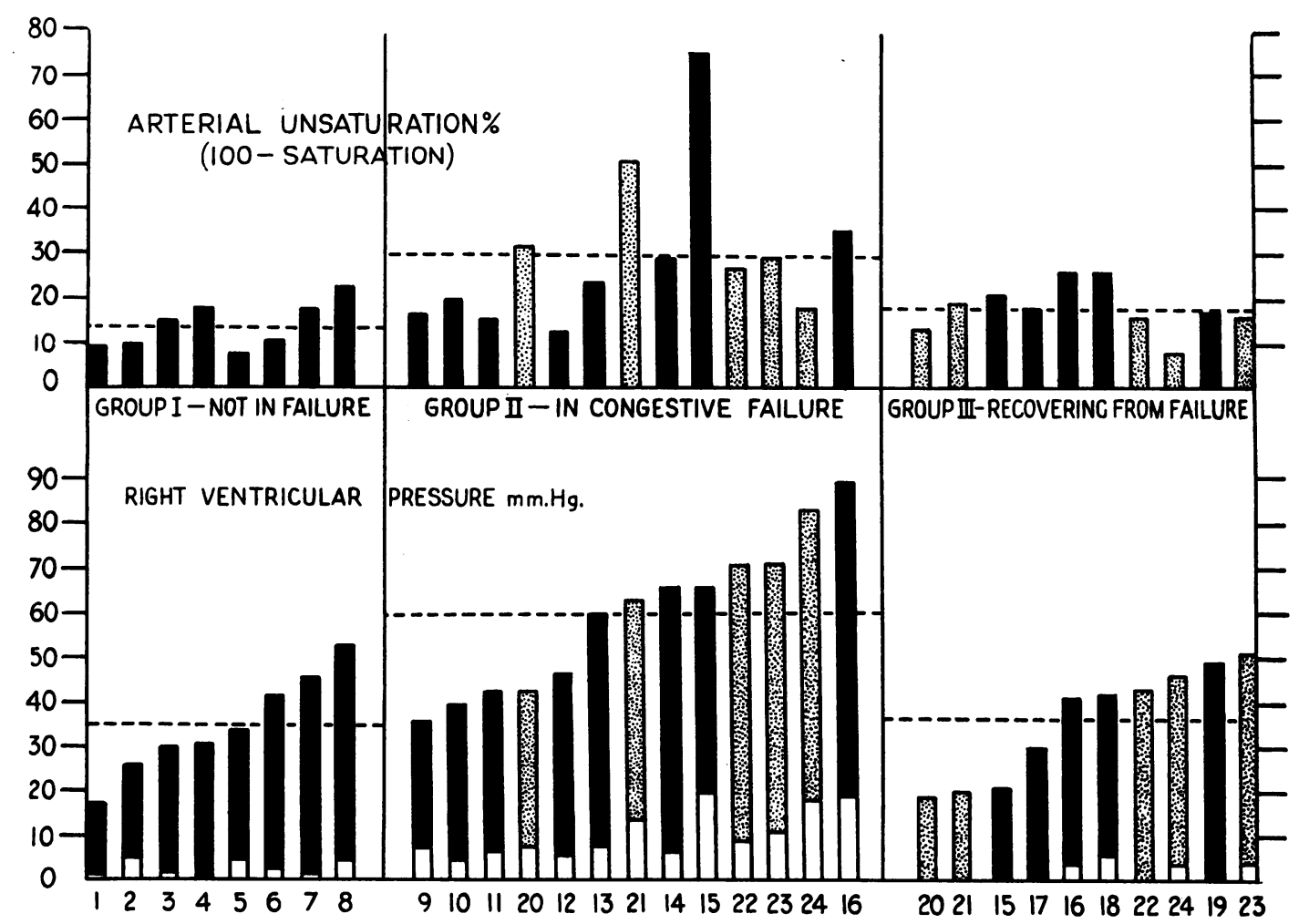

FIG. 3.-Right ventricular pressures and arterial oxygen unsaturations of the 24 patients at rest. Peak systolic pressure is indicated by the shaded portion of the bar; end-diastolic pressure, by the clear portion of the bar. Mean values for the three groups are shown by the horizontal broken lines. Stippled bars represent those patients who were studied twice during a single hospital admission for congestive cardiac failure.

The right ventricular pressures found in our patients are depicted in Fig. 3. The average systolic pressure was considerably raised in the presence of congestive cardiac failure, but on recovery returned to a level almost identical with that found in the patients who had never been in failure. This general observation was clearly confirmed by the findings in the five patients who were studied twice during a single admission for congestive failure (indicated in the figure by stippled bars). Each showed a significant lowering of pressure on recovery; in two pressures returned entirely to normal. Similar alterations of pressure in cor pulmonale have been reported by Ferrer et al. (1950).

While this sequence of right ventricular pressure changes is the same as that seen in left ventricular failure and recovery, the mechanism must, of necessity, be different. When the left ventricle fails,

\footnotetext{
* Systolic right ventricular and pulmonary arterial pressures are identical.
} 
its end-diastolic pressure rises, and, as a consequence of this, the left atrial, pulmonary venous, and pulmonary " capillary" pressures rise (Harvey et al., 1949; Dexter et al., 1950; Cournand, 1950). In order to maintain a proper gradient of pressure for pulmonary blood flow, therefore, the pulmonary artery pressure also rises; on recovery, all of these values return towards normal. No such mechanism, however, can account for the rise in pulmonary arterial pressure that occurs in failure of the right ventricle alone.

Fixed structural changes in the pulmonary vascular bed, which increase its rigidity or reduce its cross-sectional area, have previously been considered to play the major part in the production of high pulmonary arterial pressures in emphysema. However, since the high resting pressures observed during cardiac failure have been shown to be transitory and reversible, it is clear that permanent structural changes alone cannot be responsible. The moderate pulmonary hypertension seen at rest in some of our patients who were not in congestive failure-as also observed by Borden et al. (1950) and Harvey et al. (1951) - suggests that anatomical changes might play some role in raising the pulmonary arterial pressure. There was no correlation, however, between the residual air percentage, as indicating the extent of the emphysema, and the right ventricular pressure in these severely emphysematous subjects, although in patients with mild emphysema (Harvey et al., 1951) and consequently with less abnormal residual air percentages, the pulmonary pressures were less frequently raised.

Pulmonary hypertension may sometimes be present without any reduction in the pulmonary capillary bed from alveolar destruction. Case 15, whose general findings have been reported elsewhere (Clinico-Pathological Conference, 1951), illustrates this point. When initially studied, during recovery from congestive failure, there were entirely normal right ventricular pressures. On

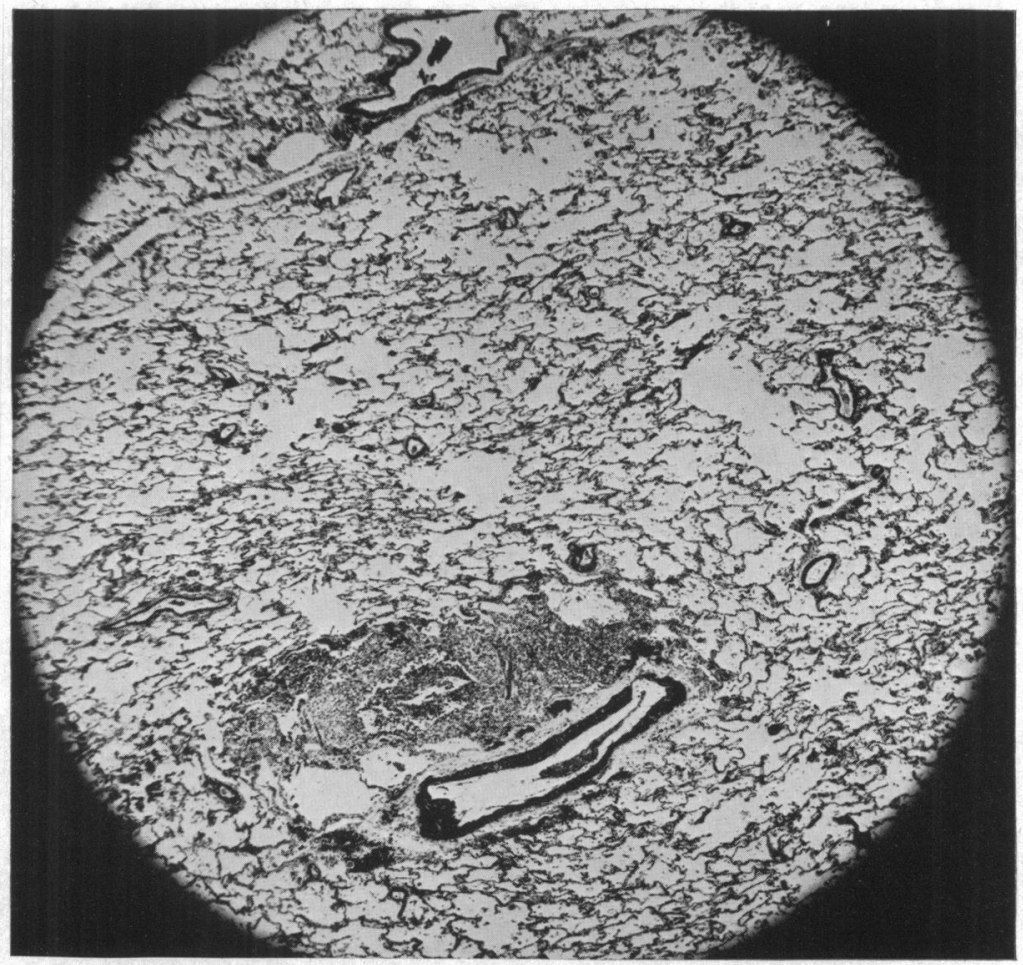

FIG. 4.-A typical microscopic field of lung showing minimal destruction of alveoli, normal vascular channels, and an inflammatory lesion of a bronchiole (Magnification, $\times 21 ; H$. and E. stain). From necropsy of Case 15. 


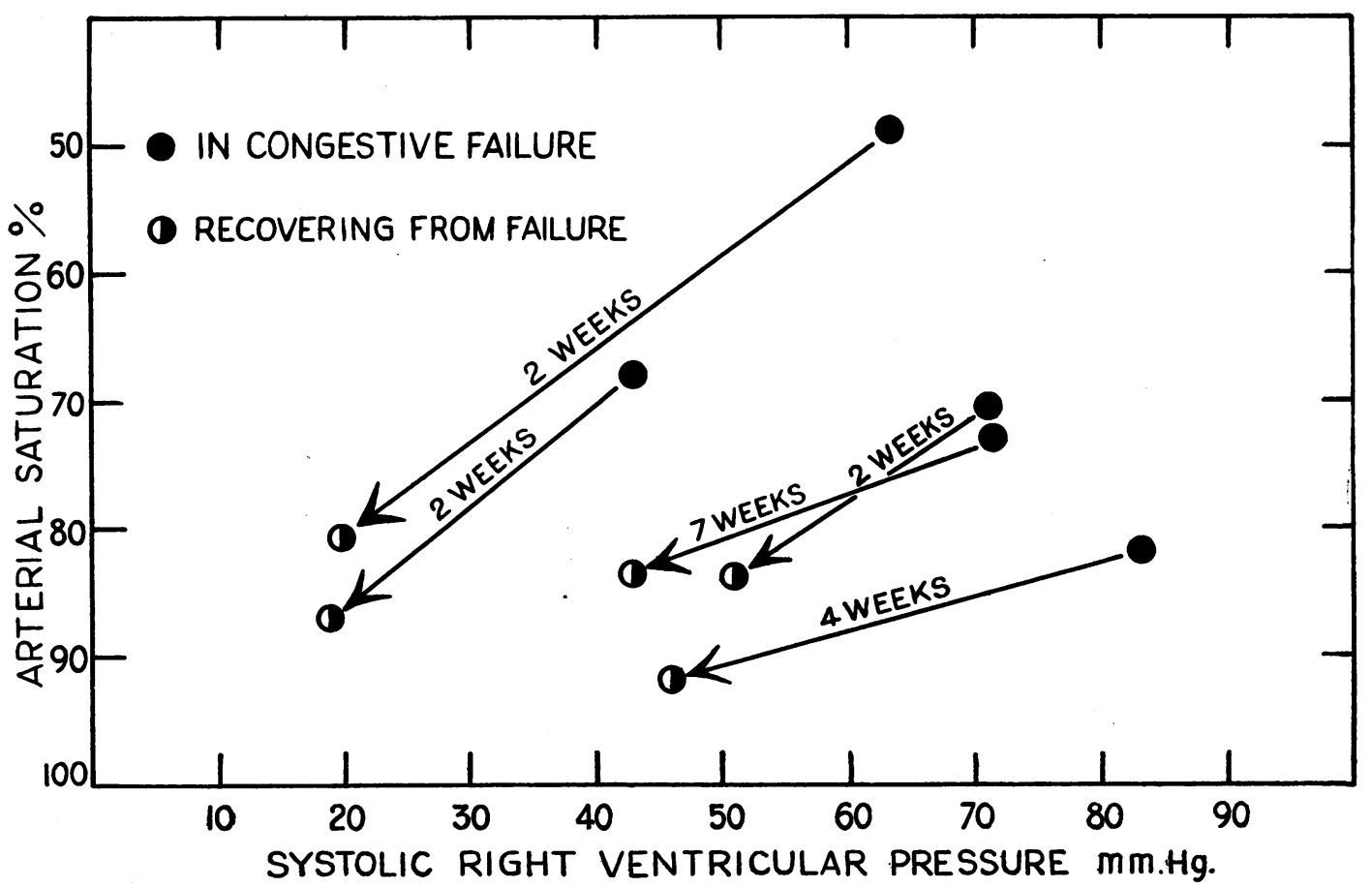

Fig. 5.-Changes in right ventricular systolic pressure and arterial oxygen saturation at rest in five patients during recovery from congestive cardiac failure.

cardiac catheterization 15 months later, one day before death, the right ventricular pressure was found to be $66 / 20 \mathrm{mg}$. Hg. Post mortem, the predominant pathological finding was an acute and chronic bronchiolitis, with well-preserved alveoli. The impaired pulmonary function in this patient is explicable on the basis of changes in the air passages alone and no anatomical explanation is apparent for the terminal pulmonary hypertension.

Certain functional changes, therefore, must be considered in the mechanism of production of pulmonary hypertension in chronic emphysema. The average arterial saturation was greatly decreased when patients were in congestive failure and had raised right ventricular pressures, but, with recovery from failure, the average saturation returned to a higher level as the pressure fell (Fig. 3). This association between a fall in pressure and a rise in arterial saturation is more clearly seen in the five patients studied on two occasions both in, and during recovery from, failure (Fig. 5). The correlation in our series (Fig. 6) of arterial oxygen saturations and right ventricular pressures $(\mathrm{r}=0.516 ; \mathrm{P}<0.01)$ is in agreement with the findings of Borden et al. (1950) and Harvey et al. (1951) which show a relationship between anoxia and pulmonary hypertension. This suggests that the pulmonary hypertension in emphysema may be related to the experimental pulmonary hypertension found in animals and normal men during exposure to low oxygen tensions (von Euler and Liljestrand, 1946; Motley et al., 1947). In our series, however, the immediate correction of anoxia by the administration of oxygen did not affect the right ventricular pressure in 11 of the 14 patients so studied. Of the three in whom there was a significant reduction in pressure, the control level was raised in two, but in neither of these was the fall sufficient to bring the pressure to normal. A possible complicating factor, however, may have been the associated increase in arterial $\mathrm{CO}_{2}$ tension known to occur in emphysematous subjects breathing high oxygen mixtures (Taquini et al., 1948). Slight pulmonary vasoconstriction has been produced in animals by increasing the $\mathrm{CO}_{2}$ tension alone (von Euler and Liljestrand, 1946; Duke, 1950). 


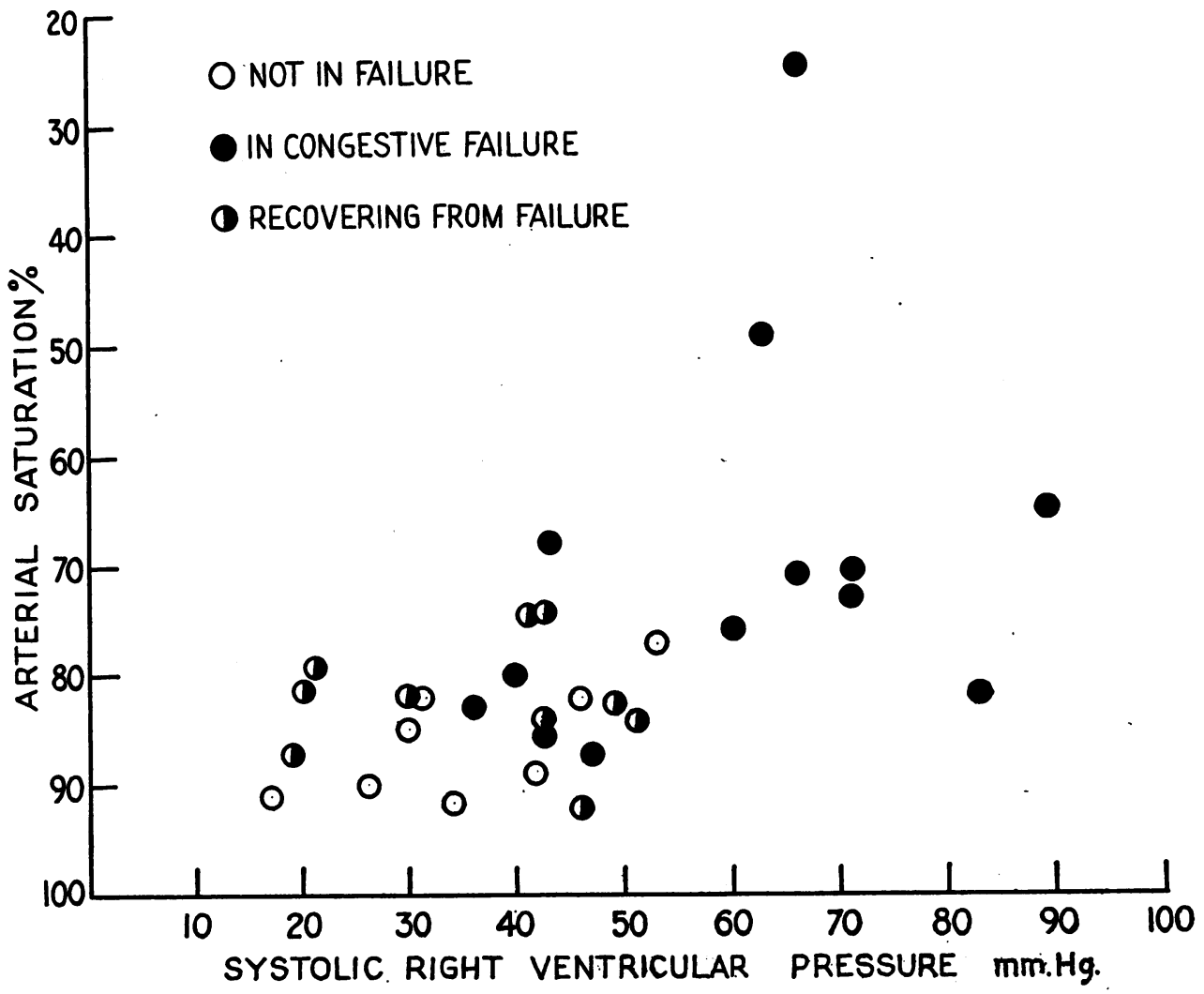

FIG. 6.-Relationship between the arterial oxygen saturation and the right ventricular systolic pressure at rest $(r=0.516 ; P<0.01)$.

A less direct relationship of anoxia to pulmonary hypertension may be postulated through its effect on blood volume. As shown by Hurtado et al. (1945), chronic anoxia may cause an increase in blood volume, predominantly by increasing the red cell mass. In this series, however, although blood volumes were not actually measured, no correlation $(r=0.042)$ was observed between the arterial saturation and the hæmoglobin concentration (Fig. 7). Nevertheless, an increased hæmoglobin concentration was noted to occur more frequently in those patients with or recovering from congestive failure. This is in agreement with previous observations by Ferrer et al. (1950) and Harvey et al. (1951) that in chronic cor pulmonale in failure, unlike other types of heart failure (Gibson and Evans, 1937; Meneely and Kaltreider, 1943), the red cell volume increases out of proportion to the plasma volume. Since all of these investigators found that a fall in blood volume usually occurs on recovery from heart failure, it is quite possible that such reduction in engorgement of the circulation may be one of the factors contributing to the observed fall in pulmonary arterial pressure.

Alterations in the pulmonary blood flow in emphysema may also influence the magnitude of the pulmonary vascular pressure. As shown by Hickam and Cargill (1948) and Riley et al. (1948), the pulmonary arterial pressure in emphysematous subjects rises sharply during exercise as the cardiac output increases. Our observations confirm these findings. Normal subjects, in contrast, show little or no alteration in pulmonary arterial pressure with changes in blood flow (Dexter et al., 1950, 1951; Riley et al., 1948; Hickam and Cargill, 1948). The abnormal response to an increased flow in emphysematous patients during exercise has been explained as resulting both from restricted capacity and limited distensibility of the pulmonary vascular bed. At rest, however, it is unlikely 


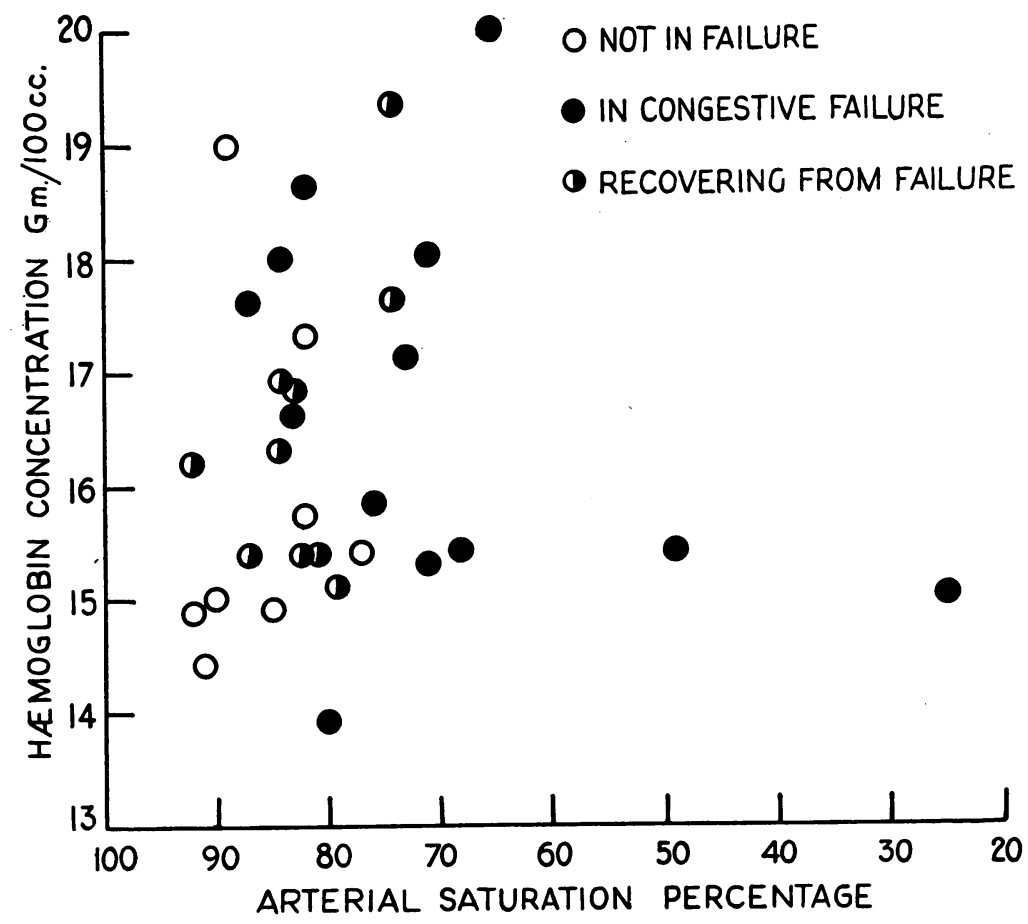

FIG. 7.-Relationship between the arterial oxygen saturation and the hæmoglobin concentration $(r=0.042)$.

that levels of flow are high enough to be directly responsible for the production of pulmonary hypertension since, in our group of patients, the cardiac index bore no relation to the height of the right ventricular pressure, as shown in Fig. $8(\mathrm{r}=0 \cdot 11)$. Moreover, in the five patients followed during recovery from failure, while resting right ventricular pressures were restored towards normal in each case, this pressure fall was found with an increased cardiac index in three, and with a decreased index in two (Fig. 9).

The extent to which neurogenic activity influences circulation through the pulmonary vascular bed in man remains uncertain. Fowler et al. (1950) have suggested, on the basis of experiments with tetra-ethylammonium chloride, that in some cases of pulmonary hypertension, including pulmonary emphysema, increased pulmonary arteriolar resistance is mediated partially through the autonomic nervous system.

High Output Failure. In an effort to clarify the meaning of the term "high output failure" in relation to chronic cor pulmonale, it has seemed worth while to examine the two factors that determine the level of the cardiac output as measured by the Fick principle-the oyxgen consumption and the arterio-venous oxygen difference. As Hickam and Cargill (1948) pointed out, normal values for either the cardiac output or arterio-venous oxygen difference are of significance only when related to the level of oxygen consumption at a particular time, i.e. the metabolic need of the body tissues for oxygen. In Fig. 10 oxygen consumption at rest is plotted against the arteriovenous oxygen difference. Three values for the cardiac index-10, 5 and $2.51 . / \mathrm{min}$./sq. metre are indicated by diagonal lines. The area for normal values is based on the findings of Stead et al. (1945), Hickam and Cargill (1948), Riley et al. (1948), and Dexter (1950, 1951) in normal subjects, at rest and on exercise. It will be seen from the diagram that, with only two exceptions, all of the subjects in this series-irrespective of the presence or absence of cardiac failure-had normal arterio- 


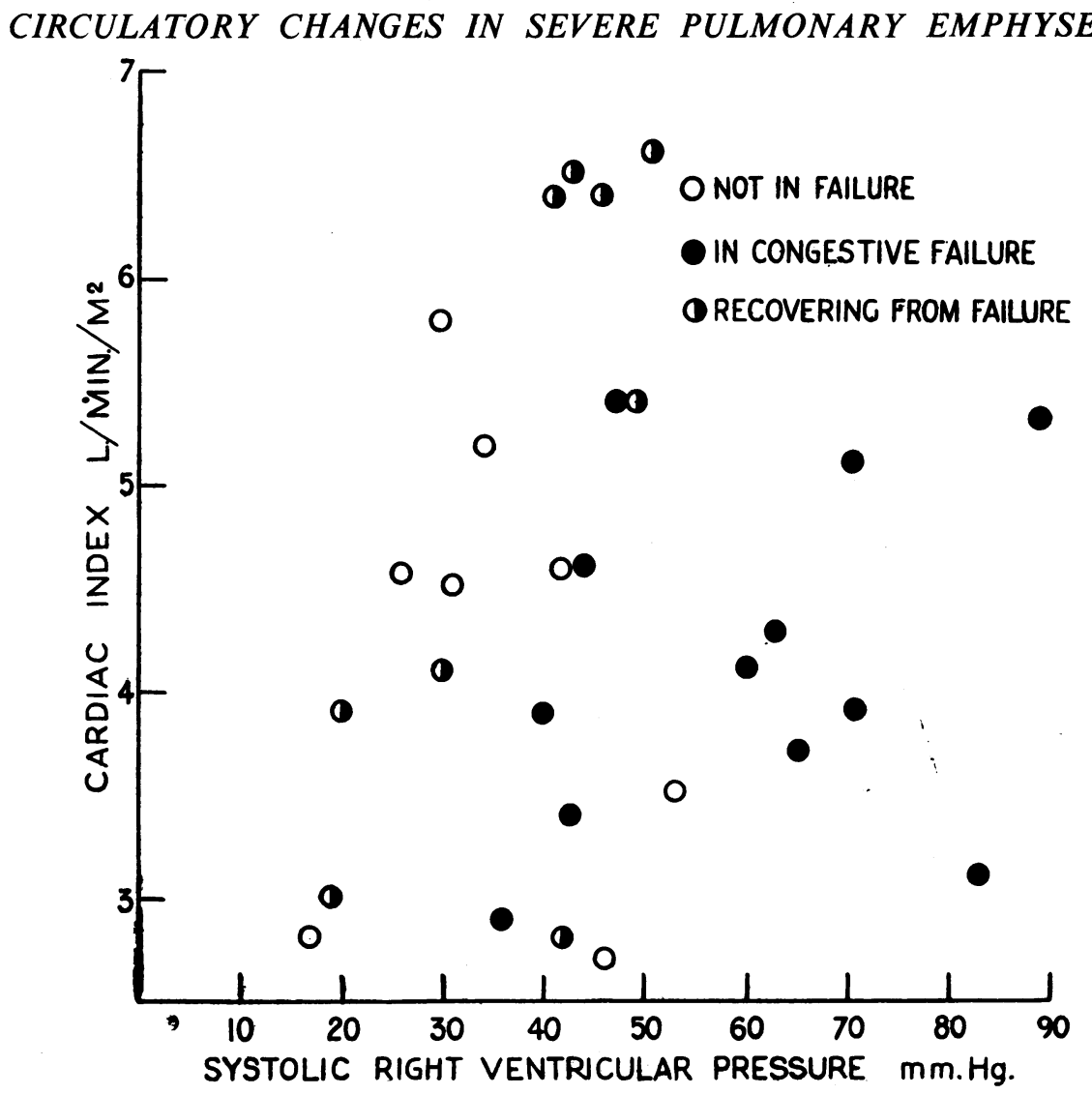

FIG. 8.-Relationship between the cardiac index and the systolic right ventricular pressure $(r=0 \cdot 11)$.

venous oxygen differences. The high resting oxygen consumptions in our series partially reflect the laboured breathing frequently present at the time of study. The increased oxygen consumptions, therefore, in combination with the normal arterio-venous oxygen differences, were responsible for the increased values for the cardiac index. In other studies also (Richards, 1945; Ferrer et al., 1950; Borden et al., 1950; Harvey et al., 1951) the arterio-venous oxygen differences have usually been found to be normal in pulmonary heart disease, and it would thus seem that failure of the circulation in cor pulmonale occurs with a cardiac output appropriate to a particular level of oxygen consumption-in reality, therefore, "normal output failure." The term " high output failure" should probably be reserved for those instances where the arterio-venous oxygen difference is lower than normal, as in cases of chronic, severe anæmia (Brannon et al., 1945; Sharpey-Schafer, 1944). Similarly, in " low output failure," as in hypertensive heart disease, for example, the arterio-venous oxygen differences are high (Bloomfield et al., 1948; Harvey et al., 1949).

The Immediate Effects of Digitalis. The increase in right ventricular pulse pressure noted in our patients after the intracardiac administration of cardiac glycosides resulted from a rise in the systolic as well as a fall in the end-diastolic pressure. In two patients these changes were unassociated with slowing of the heart rate, and in none was there a significant alteration in cardiac output. Ferrer et al. (1950) reported similar findings in cor pulmonale, but noted a consistent slight rise in cardiac output.

On catheterization of the right heart in left ventricular failure the major effect upon the pulmonary circulation observed after giving digitalis has been a reduction of raised pulmonary arterial pressures towards normal (Bloomfield et al., 1948; Harvey et al., 1949; Bayliss et al., 1950). This has been 


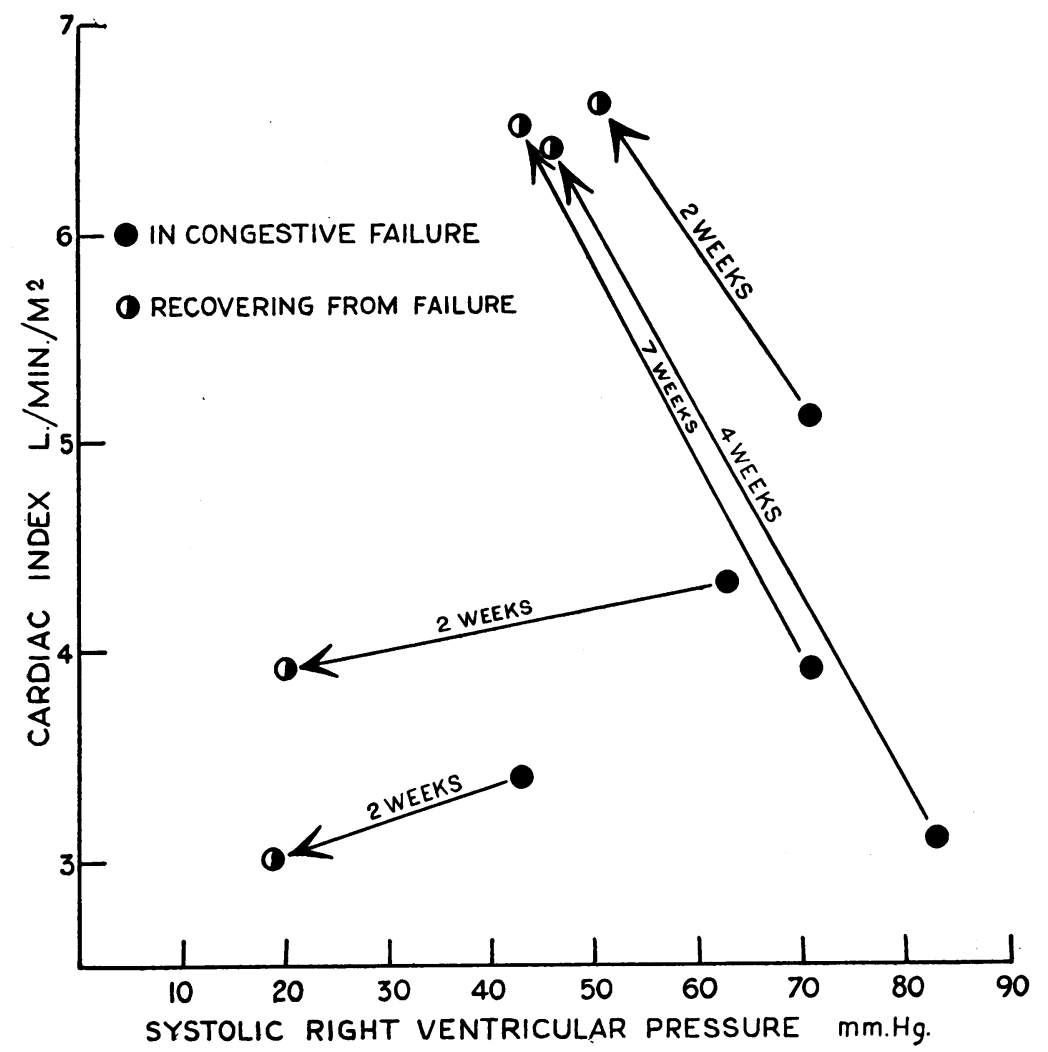

FIG. 9.-Changes in the cardiac index and the right ventricular systolic pressure at rest in five patients during recovery from congestive cardiac failure.

explained by a direct action of digitalis on the myocardium, which is responsible for better emptying of the left ventricle, and, as a result of this, for a decrease in pressures in the left atrium and pulmonary circuit. In right ventricular failure, however, both in this series and in that of Ferrer et al. (1950), the peak pulmonary artery pressure rose slightly after digitalization. Probably, this difference in response to digitalis does not indicate a different mode of action of the drug, but the different mechanism of production of pulmonary hypertension in right and in left heart failure, which has already been discussed. The cause for the rise in systolic pulmonary arterial pressure is not clear since, in contrast to the series of Ferrer et al. (1950) where a consistent rise in cardiac output occurred and an increase in blood flow was, therefore, postulated as the ætiological factor, in our cases no significant change in cardiac output was observed. The lower filling pressure of the right ventricle, however, with the maintenance of the same cardiac output, probably indicated improvement in myocardial function.

\section{SummaRY AND CONCLUSIONS}

Twenty-four patients with pulmonary emphysema have been investigated. All had grossly abnormal respiratory function; the severity of the pulmonary disease was the same in the patients with secondary right heart failure and in those who had never developed failure.

On cardiac catheterization, in the absence of congestive failure, right ventricular systolic pressures were found to be normal or only moderately raised; but in the presence of failure, they were raised in every case. As patients recovered from failure, their right ventricular pressures returned towards 


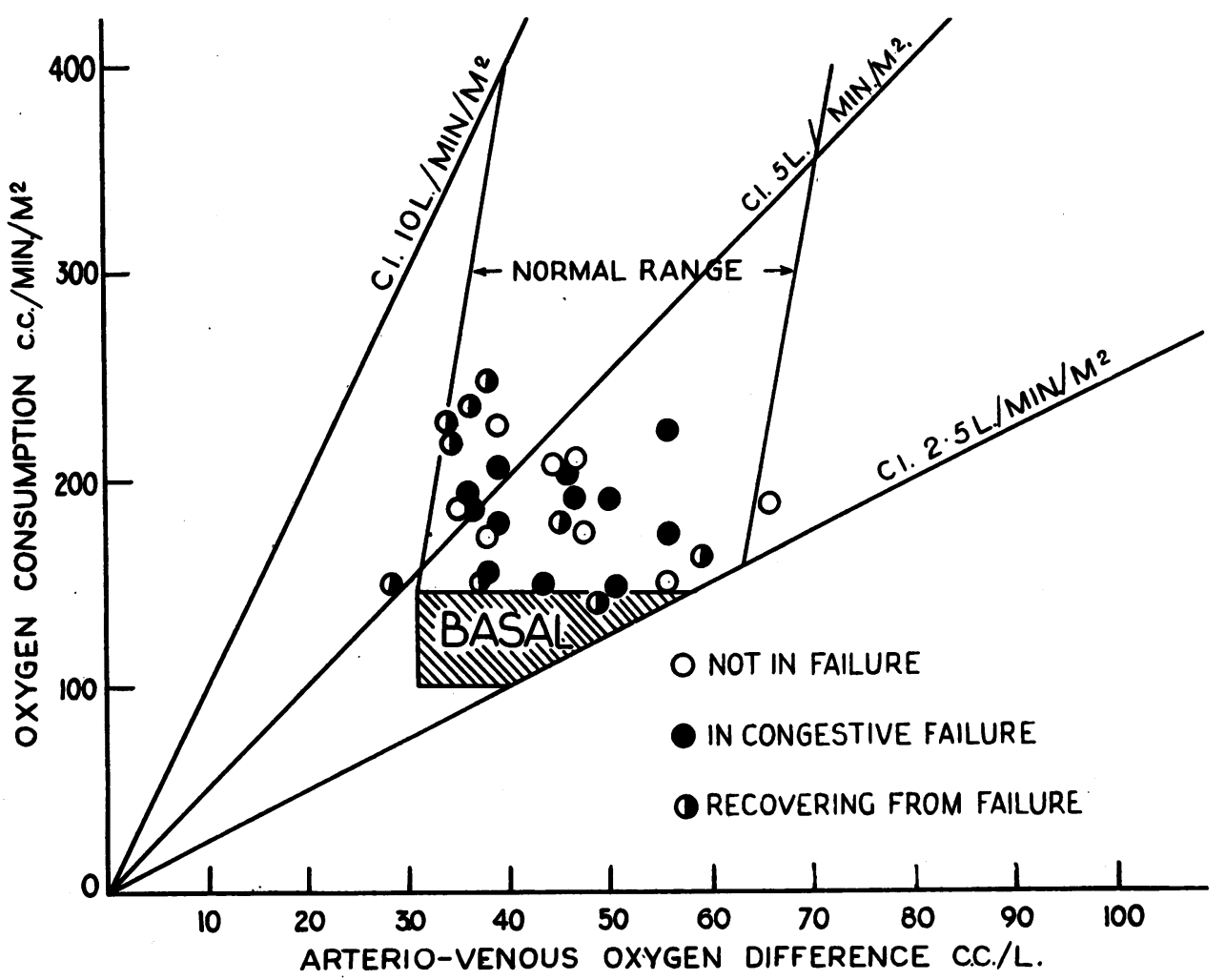

FIG. 10.-Relationship of the oxygen consumption, arterio-venous oxygen difference, and the cardiac index at rest.

normal. Pulmonary hypertension in emphysema heart failure is, therefore, reversible; it cannot result solely from fixed anatomical changes in the vascular bed of the lungs.

Certain functional changes in the circulation that may be related to the production of pulmonary hypertension in chronic bronchitis and emphysema have been considered. The high systolic pulmonary arterial pressures found in congestive heart failure were associated with low arterial oxygen saturation, but the correction of anoxia by the administration of oxygen did not usually produce a fall in pressure. During exercise a transient increase in systolic pulmonary arterial pressure was observed in these patients, indicating that pulmonary hypertension might be related to an increased blood flow. Under resting conditions, however, there was no correlation between the level of pressure and the cardiac index. A slight, but significant, increase in hæmoglobin concentration was associated with the development of cardiac failure. It is possible that an increase in red cell volume may contribute to pulmonary hypertension as part of a general vascular engorgement.

Arterio-venous oxygen differences were normal in all except two cases, whether or not failure was present. Raised cardiac outputs were predominantly the result of an increase in resting oxygen consumption.

The immediate effects of full doses of cardiac glycosides were observed in five patients. The right ventricular pulse pressure was increased in each case without a significant change in cardiac output. The maintenance of a higher pulse pressure at a lower diastolic filling pressure probably signifies some improvement in myocardial function.

We wish to acknowledge with sincere thanks the help of Prof. J. McMichael, under whose guidance this study has been carried out, and the assistance of other members of the staff who performed some of the cardiac catheterizations.

We are grateful for technical help to Mr. Arthur H. Latham, Miss Margot McAdam, Miss Zeena Taylor, Mr. Trevor Mills, and Mr. Roy Barrett. We wish to thank Miss Patricia Burrows for drawing the charts and figures, and Mr. E. Victor Wilmott for preparing the photographic material. 


\section{REFERENCES}

Baldwin, E. de F., Cournand, A., and Richards, D. W., Jnr. (1949). Medicine, $28,201$.

Bates, J. V., and Christie, R. V. (1950). Clin. Sci., 9, 17.

Bayliss, R. I. S., Etheridge, M. J., Hyman, A. L., Kelly, H. G., McMichael, J., and Reid, E. A. S. (1950). Brit. Heart J., $12,317$.

Bloomfield, R. A., Rapoport, B., Milnor, J. P., Long, W. K., Mebane, J. G., and Ellis, L. B. (1948). J. clin. Invest., 27, 588.

Borden, C. W., Wilson, R. H., Ebert, R. V., and Wells, H. S. (1950). Amer. J. Med., 8, 701.

Brannon, E. S., Merrill, A. J., Warren, J. V., and Stead, E. A., Jr. (1945). J. clin. Invest., $24,332$.

Briscoe, W. A. (1951). M.D. Thesis for Oxford University. Becklake, M. R., and Rose, T. F. (1951). Clin. Sci., 10, 37

Clinico-pathological Conference No. 10 (1951). Postgrad. med. J., 27, 25.

Cournand, A. (1950). Circulation, 2, 641.

Dexter, L., Dow, J. W., Haynes, F. W., Whittenberger, J. L., Ferris, B. G., Goodale, W. T., and Hellems, H. K. (1950). J. clin. Invest., 29, 602.

_, Whittenberger, J. L., Haynes, F. W., Goodale, W. T., Gorlin, R., and Sawyer, C. G. (1951). J. appl. Physiol., 3, 439.

Duke, H. N. (1950). Quart. J. exper. Physiol., 35, 25.

von Euler, U. S., and Liljestrand, G. (1946). Acta physiol. Scand., 12, 301.

Ferrer, M. I., Harvey, R. M., Cathcart, R. T., Webster, C. A., Richards, D. W., Jr., and Cournand, A. (1950). Circulation, 1, 161 .

Fowler, N. O., Westcott, R. M., Hauenstein, V. D., Scott, R. C., and McGuire, J. (1950). J. clin. Invest., $29,1387$.

Gibson, J. B., 2nd, and Evans, W. A., Jr. (1937). J. clin. Invest., 16, 851.

Harvey, R. M., Ferrer, M. I., Cathcart, R. T., Richards, D. W., Jr., and Cournand, A. (1949). Amer. J. Med., 4, 439.

- Ferrer, M. I., Richards, D. W., Jr., and Cournand, A. (1951). Amer. J. Med., 10, 719.

Hickam, J. B., and Cargill, W. H. (1948). J. clin. Invest., 27, 10.

Hurtado, A., Merino, C., and Delgado, E. (1945). Arch. intern. Med., 75, 284.

Latham, A. H. (1950). J. Soc. Cardiol. Technicians of Gt. Brit., 1, 68.

McMichael, J. (1939). Clin. Sci., 4, 167.

$\longrightarrow$, and Sharpey-Schafer, E. P. (1944). Quart. J. Med., N.S., 13, 123.

Meneeley, G. R., and Kaltreider, N. L. (1943). J. clin. Invest., 22, 521.

Motley, H. L., Cournand, A., Werkö, L., Himmelstein, A., and Dresdale, D. (1947). Amer. J. Physiol., $150,315$.

Mounsey, J. P. D., Ritzmann, L. W., and Selverstone, N. J., unpublished.

Richards, D. W., Jr. (1945). Fed. Proc., 4, 215.

Riley, R. L., Himmelstein, A., Motley, H. L., Weiner, H. M., and Cournand, A. (1948). Amer. J. Physiol., $152,372$.

Sharpey-Schafer, E. P. (1944). Clin. Sci., 5, 125.

Simpson, T. (1948). Brit. med. J., 2, 639.

Stead, E. A., Jr., Warren, J. V., Merrill, A. J., and Brannon, E. S. (1945). J. clin. Invest., $24,326$.

Taquini, A. C., Fasciolo, J. C., Suarez, J. R. E., and Chiodi, H. (1948). Arch. intern. Med., 82, 534.

Whitehorn, W. V., Edelmann, A., and Hitchcock, F. A. (1946). Amer. J. Physiol., 146, 61. 